\title{
Carbon stocks and dynamics at different successional stages in an Afromontane tropical forest
}

\author{
Brigitte Nyirambangutse $^{1,2}$, Etienne Zibera ${ }^{2}$, Félicien K. Uwizeye ${ }^{2}$, Donat Nsabimana ${ }^{2}$, Elias Bizuru $^{2}$, Håkan Pleijel ${ }^{1}$, \\ Johan Uddling ${ }^{1}$, and Göran Wallin ${ }^{1}$ \\ ${ }^{1}$ Department of Biological and Environmental Sciences, University of Gothenburg, P.O. Box 461, 405 30, Sweden \\ ${ }^{2}$ Department of Biology, University of Rwanda, University Avenue, P.O. Box 117, Huye, Rwanda
}

Correspondence to: Brigitte Nyirambangutse (brigittenyiridandi@gmail.com)

and Göran Wallin (goran.wallin@ bioenv.gu.se)

Received: 23 August 2016 - Discussion started: 6 September 2016

Revised: 21 December 2016 - Accepted: 3 January 2017 - Published: 15 March 2017

\begin{abstract}
As a result of different types of disturbance, forests are a mixture of stands at different stages of ecological succession. Successional stage is likely to influence forest productivity and carbon storage, linking the degree of forest disturbance to the global carbon cycle and climate. Although tropical montane forests are an important part of tropical forest ecosystems (ca. $8 \%$, elevation $>1000$ m a.s.l.), there are still significant knowledge gaps regarding the carbon dynamics and stocks of these forests, and how these differ between early (ES) and late successional (LS) stages. This study examines the carbon (C) stock, relative growth rate (RGR) and net primary production (NPP) of ES and LS forest stands in an Afromontane tropical rainforest using data from inventories of quantitatively important ecosystem compartments in fifteen 0.5 ha plots in Nyungwe National Park in Rwanda.

The total C stock was $35 \%$ larger in LS compared to ES plots due to significantly larger above-ground biomass (AGB; 185 and $76 \mathrm{MgC} \mathrm{ha}^{-1}$ in LS and ES plots), while the soil and root $\mathrm{C}$ stock (down to $45 \mathrm{~cm}$ depth in the mineral soil) did not significantly differ between the two successional stages (178 and $204 \mathrm{MgCha}^{-1}$ in LS and ES plots). The main reasons for the difference in AGB were that ES trees had significantly lower stature and wood density compared to LS trees. However, ES and LS stands had similar total NPP (canopy, wood and roots of all plots $\sim 9.4 \mathrm{MgCha}^{-1}$ ) due to counterbalancing effects of differences in AGB (higher in LS stands) and RGR (higher in ES stands). The AGB in the LS plots was considerably higher than the average value reported for old-growth tropical montane forest of south-east Asia and Central and South America at similar elevations and
\end{abstract}

temperatures, and of the same magnitude as in tropical lowland forest of these regions.

The results of this study highlight the importance of accounting for disturbance regimes and differences in wood density and allometry of tree species dominating at different successional stages in an attempt to quantify the $\mathrm{C}$ stock and sink strength of tropical montane forests and how they may differ among continents.

\section{Introduction}

Tropical forests store 40-50\% of the carbon (C) in terrestrial biomass (Phillips et al., 1998; Lewis et al., 2009) and account for one-third of global terrestrial net primary productivity (Saugier et al., 2001; Malhi et al., 2014b), thereby contributing significantly to the global $\mathrm{C}$ cycle and climate. In addition to their influence on climate, tropical forests also provide other important ecosystem services such as food, wood products, erosion control, biodiversity protection and water regulation (Costanza et al., 1997; Alamgir et al., 2016). Tropical montane forests (TMFs) cover ca. $8 \%$ (elevation $>1000 \mathrm{ma}$ a.s.l.) of the total tropical forest area (Spracklen and Righelato, 2014) and are considered particularly important for harbouring biodiversity and water regulation (Martínez et al., 2009; Scatena et al., 2011). Studies indicate that TMF has been underestimated with respect to its capacity to store (Spracklen and Righelato, 2014) and sequester (Fehse et al., 2002) C. However, the current understanding of the role of TMFs in regulating global biogeochemical cycles 
is hampered by the paucity of field data on productivity and soil C, but also biomass, especially from the African continent (Malhi et al., 2013a, b; Spracklen and Righelato, 2014). Our current understanding of $\mathrm{C}$ storage in tropical forests is to a large extent based on studies of lowland forests in South America and south-east Asia. Despite of being the world's second largest tropical forest block, African tropical forests have drawn little attention in terms of $\mathrm{C}$ cycling research compared to their counterparts in South America and southeast Asia (Lewis et al., 2009; Malhi et al., 2013a, b).

A recent review indicated that the above-ground biomass (AGB) in central African lowland forest is higher compared to lowland forests in central and eastern Amazonia (Lewis et al., 2013), which may be related to differences in climate, soil, biodiversity and/or legacy of disturbance. Ensslin et al. (2015) suggested that AGB may also be higher in African TMFs compared to those in South America. However, because of the low number of studies in Africa it is currently difficult to draw any conclusions about the differences in biomass of TMFs of the two continents. Even for basic forest attributes such as biomass, stand structure, species diversity and composition, the number of African studies of both lowland and montane forest is low (Lewis et al., 2013; Spracklen and Righelato, 2014; Bastin et al., 2015).

There is a growing number of studies conducted in lowland tropical forests, focusing on estimates of net primary productivity (NPP), gross primary productivity (GPP) and C allocation (Aragão et al., 2009; Doughty et al., 2014; Malhi et al., 2014a). Such studies are still few in TMFs, causing large uncertainty regarding the $\mathrm{C}$ fluxes of these ecosystems (Girardin et al., 2014a; Spracklen et al., 2016). In general, TMFs are thought to have low productivity compared to lowland tropical forests (Bruijnzeel and Veneklaas, 1998; Girardin et al., 2014a; Huasco et al., 2014), but this is not always the case (Fehse et al., 2002). Up to now, no studies of productivity have been reported for African TMFs.

Most tropical forests are a mix of disturbed and undisturbed stands, denoted secondary and primary (or oldgrowth) forests. Secondary forests are defined as forest regenerating largely through natural processes after significant human and/or natural disturbance (Chokkalingam and de Jong, 2001). The detailed distribution of this forest type remains uncertain due to large variation in how this forest type has been defined in the literature with respect to the degree of disturbance. However, secondary forests account for at least 40 to $60 \%$ of the total tropical forest area and are therefore considered to be very important, both ecologically and economically (Brown and Lugo, 1990; FAO, 2010), as well as being an important part of the global C cycle (Birdsey and Pan, 2015; Noormets et al., 2015). Their fraction is expected to increase in several tropical regions as the human pressure is likely to continue increasing over the coming decades (Lewis et al., 2015), e.g. in central Africa (Feintrenie, 2014). In spite of their importance and frequent occurrence, tropical secondary forests have received compar- atively little attention as the majority of studies reported so far have focused on old-growth tropical forests (Clark et al., 2001; Malhi et al., 2014b). The C uptake and storage of secondary forests is therefore still highly uncertain (Pan et al., 2011). Secondary forests are characterized by a high abundance of early successional (ES) tree species, which will be successively replaced by late successional (LS) tree species dominating in undisturbed old-growth forests. This replacement may take several decades to centuries (Peña-Claros, 2003; Liebsch et al., 2008; Martin et al., 2013) and since the ES species grow faster, but may have a lower stature and wood density $(\rho)$ than LS species (Lawton, 1984; Poorter et al., 2008; Gustafsson et al., 2016), both the productivity and the forest $\mathrm{C}$ stock are likely to change during successional progression. However, although studies of secondary forests indicate that they have high above-ground productivity and C sink strength (Sierra et al., 2012), below-ground compartments have rarely been investigated (Berenguer et al., 2014).

Quantification of both biomass and productivity rely on established tree allometric relations. Such relations formulated as equations may be generic (based on multiple tree species harvested in many different sites), site and species specific, or something in between (Chave et al., 2005, 2014; Jara et al., 2015). Chave et al. (2005) showed that the most important parameters in estimating biomass in pantropical forests were (in decreasing order of importance) trunk diameter, $\rho$, tree height $(H)$ and forest type. Thus, to substantially improve allometric estimates of forest biomass in African forests, more information on these variables is needed for key tree species in different types of forest (Gibbs et al., 2007; Kearsley et al., 2013; Lewis et al., 2013). Height has mostly been omitted in early estimates of tropical forest biomass (Feldpausch et al., 2011), but when included it reduced the standard error from 19.5 to $12.5 \%$ in the pantropical biomass estimates (Chave et al., 2005). Moreover, the use of pantropical allometric equations where $H$ was not incorporated caused a $52 \%$ biomass overestimation in TMFs compared to when $H$ was incorporated (Girardin et al., 2010). When $H$ is incorporated in the biomass estimations, it is normally calculated from $H$ vs. $D$ relationships established from measurements of subsamples of trees. Since the $D$ vs. $H$ relationship may vary greatly among forest types and regions, specific information on this trait is critical to accurately estimate forest biomass (Feldpausch et al., 2011; Kearsley et al., 2013). Furthermore, most studies today apply species- or genus-specific $\rho$ data available in a rather comprehensive database (Chave et al., 2009; Zanne et al., 2009). However, $\rho$ data are still lacking for many important tropical tree species and there may also be considerable variation in this trait within a given species, likely due to variation in environmental conditions among sites (Muller-Landau, 2004). Species-specific on-site information for key species may therefore be valuable, and in studies investigating the influence of successional stages on forest biomass. 
With the overall aim of reducing the knowledge gap regarding the $\mathrm{C}$ balance of African TMFs, we quantified $\mathrm{C}$ stocks and productivity of 15 half-hectare plots with mature trees, but with different disturbance histories and different abundances of early and late successional tree species (ES and LS tree species). We assessed above- and below-ground C stocks, tree recruitment and mortality, and NPP of leaves, wood and roots. We hypothesized that (1) tree biomass and total C stock is higher in LS compared to ES stands; (2) trees in ES stands are smaller but have higher relative growth rates compared to trees in LS stands, resulting in similar NPP at both successional stages; (3) it is critical to account for variation in allometric relations and $\rho$ when quantifying and comparing forest biomass at different successional stages, since ES and LS species differ in these traits; (4) C stocks are higher in the African TMF studied here compared to TMFs in South America.

\section{Material and methods}

\subsection{Study area}

The study was conducted in Nyungwe tropical montane rainforest located in south-western Rwanda $\left(2^{\circ} 17^{\prime}-2^{\circ} 50^{\prime} \mathrm{S}\right.$, $29^{\circ} 07^{\prime}-29^{\circ} 26^{\prime} \mathrm{E}$ ), ranging from 1600 to $2950 \mathrm{~m}$ a.s.l. Nyungwe forest was gazetted as a national park in 2004 (Gross-Camp et al., 2012). It covers an area of $1013 \mathrm{~km}^{2}$ and is the largest remaining middle-elevation montane rainforest in central Africa. It hosts a large biodiversity, supporting approximately 1105 vascular plant species (of which 230 are trees), 280 bird species and is home to 13 species of primates (Plumptre et al., 2007). The forest contains various ecosystems ranging from dense forest and bamboo groves to marshes. Large areas consist of a mixture of primary and secondary forest (Fashing et al., 2007) due to its disturbance history (Plumptre et al., 2002; Masozera and Alavalapati, 2004; Masozera et al., 2006). The secondary forest areas are mainly created from human-induced disturbances such as tree cutting, fire and mining, but natural disturbances such as landslide and fallen trees are also significant. The soils were developed on quartzite schist, mica schist, schist and granite parent material (Cizungu et al., 2014). The mineral top soil consists of clay, sand and silt ranging from 2 to 71,9 to 61 and 5 to $61 \%$ with averages of 34, 43 and $23 \%$, respectively (Gharahi Ghehi et al., 2014). At a meteorological station located at Uwinka $\left(2^{\circ} 28^{\prime} 43^{\prime \prime} \mathrm{S}, 29^{\circ} 12^{\prime} 00^{\prime \prime}\right.$ E, $2465 \mathrm{~m}$ a.s.l. elevation, Nsabimana, 2009), the average day and night air temperatures were 15.7 and $13.5^{\circ} \mathrm{C}$, the relative humidity was $81 \%$ and annual rainfall was $1867 \mathrm{~mm}$ during 2007-2015. The difference between the warmest and coldest months was $1.1^{\circ} \mathrm{C}$. There is a 2 -month dry season, normally occurring from mid-June to mid-August.

\subsection{Plots}

In late 2011 and early 2012, 15 permanent plots with a planimetric area of $0.5 \mathrm{ha}(100 \times 50 \mathrm{~m})$ were established. The plots were arranged along a $32 \mathrm{~km}$-long east-west transect at an elevation of ca. 1950 to 2500 m a.s.l. (Fig. S1 in the Supplement). Forest stands ranging from a dominance of early successional (ES) to a dominance of late successional (LS) species were included, but areas with recent and extensive disturbance were excluded. The most abundant ES and LS tree species were Macaranga kilimandscharica Pax and Syzygium guineense (Engl.) Mildbr., respectively. Each plot was subdivided into eight subplots with a size of $25 \mathrm{~m} \times 25 \mathrm{~m}$. All individual woody plants with a breast height diameter $(D) \geq 5 \mathrm{~cm}$ were mapped and identified to species level when possible. The total number of identified tree species was 83. A subset of species, consisting of those that were among the four most abundant species with respect to basal area in any of the 15 plots, was selected for more detailed studies to facilitate the estimation of $\mathrm{C}$ stock and productivity. This subset comprised 22 species in total, representing $90 \%$ of the basal area and $79 \%$ of all individual stems across all 15 plots. Plot positions and climate are given in Table 1 and information on topography and stand characteristics are presented in Table S1 in the Supplement and Table 2. All forest-area-based information is related to the planimetric area.

\subsection{Meteorological data}

Data on air temperature, air humidity, solar radiation and precipitation were collected every $30 \mathrm{~min}$ from four meteorology stations installed along the transect of plots (Table 1). One major station was established at the Uwinka research site in February 2007 (Nsabimana, 2009) and three minor additional stations were established in June 2013 (Fig. S1). The Uwinka station was installed in a $15 \mathrm{~m}$ tower on a hill top so it would reach above the canopy, while the others were installed in open areas at $3 \mathrm{~m}$ height $(1.5-2 \mathrm{~m}$ above-ground vegetation). The minor stations were equipped with sensors for measurements of temperature, relative humidity, solar radiation and precipitation (VP-3, PYR/PAR and ECRN-100 from Decagon Device, Inc, Pullman, WA, USA) connected to a data logger (Em50G, Decagon Device Inc). At the major and one of the minor stations soil temperature and moisture were also measured by a thermistor (SKTS 200, Skye instruments Ltd., Powys, UK), Theta probes (ML2, Delta-T Devices Ltd., Cambridge, UK) and a combined sensor (5TM) at $10 \mathrm{~cm}$ depth. Air temperature and humidity was also measured at the centre of each plot (under the canopy) using mini-loggers (Model TinyTag Plus 2, Gemini data loggers Ltd, United Kingdom) placed inside self-ventilating radiation shields at approximately $3 \mathrm{~m}$ above the ground. 
Table 1. Temperature $(T)$ and precipitation at five locations along a $32 \mathrm{~km}$ transect with 15 plots in Nyungwe tropical montane forest during July 2013 to June 2015. Temperature at $3 \mathrm{~m}$ above ground was measured both below the canopy in each plot and at four meteorology stations in open areas. SD of plot and meteorology station data represents variation among plots and months, respectively. Plot numbers at each location are given in brackets.

\begin{tabular}{|c|c|c|c|c|c|}
\hline \multirow[b]{3}{*}{ Properties } & \multicolumn{5}{|c|}{ Locations (plots) } \\
\hline & I (1-3) & II (4-6) & III (7-9) & IV (10-12) & $\mathrm{V}(13-15)$ \\
\hline & Mean SD & Mean SD & Mean SD & Mean SD & Mean SD \\
\hline Latitude & $2^{\circ} 31^{\prime} 54^{\prime \prime} \mathrm{S}$ & $2^{\circ} 31^{\prime} 25^{\prime \prime} \mathrm{S}$ & $2^{\circ} 28^{\prime} 54^{\prime \prime} \mathrm{S}$ & $2^{\circ} 28^{\prime} 30^{\prime \prime} \mathrm{S}$ & $2^{\circ} 28^{\prime} 38^{\prime \prime} \mathrm{S}$ \\
\hline Longitude & $29^{\circ} 23^{\prime} 20^{\prime \prime} \mathrm{E}$ & $29^{\circ} 20^{\prime} 33^{\prime \prime} \mathrm{E}$ & $29^{\circ} 14^{\prime} 36^{\prime \prime} \mathrm{E}$ & $29^{\circ} 12^{\prime} 40^{\prime \prime} \mathrm{E}$ & $29^{\circ} 6^{\prime} 53^{\prime \prime} \mathrm{E}$ \\
\hline Elevation (ma.s.1.) & $2493 \pm 27$ & $2505 \pm 31$ & $2400 \pm 18$ & $2415 \pm 67$ & $1952 \pm 13$ \\
\hline \multicolumn{6}{|l|}{ Plot air temperatures, under canopy: } \\
\hline Mean annual air temperature $\left({ }^{\circ} \mathrm{C}\right)$ & $13.9 \pm 0.1$ & $13.7 \pm 0$ & $14.2 \pm 0.5$ & $14.4 \pm 0.7$ & $15.6 \pm 0.2$ \\
\hline Lowest monthly mean daily minimum $T\left({ }^{\circ} \mathrm{C}\right)$ & $11.3 \pm 0.2$ & $9.9 \pm 1$ & $10.1 \pm 2$ & $11.7 \pm 1.3$ & $10.9 \pm 0.3$ \\
\hline Highest monthly mean daily maximum $T\left({ }^{\circ} \mathrm{C}\right)$ & $17.7 \pm 0.1$ & $18.6 \pm 0$ & $19.4 \pm 0.6$ & $18.3 \pm 0.2$ & $21.2 \pm 0.9$ \\
\hline \multicolumn{6}{|l|}{ Meteorology station data, open areas: } \\
\hline Mean annual air temperature $\left({ }^{\circ} \mathrm{C}\right)$ & $14.1 \pm 0.06$ & & $14.4 \pm 0.05$ & $14.6 \pm 0.03$ & $16.1 \pm 0.01$ \\
\hline Annual precipitation $\left(\mathrm{mm} \mathrm{year}^{-1}\right)$ & $1657 \pm 163$ & & $1755 \pm 300$ & $1860 \pm 116$ & $3016 \pm 63$ \\
\hline
\end{tabular}

\subsection{Stem mass and NPP}

The $D$ of all trees with $D \geq 5 \mathrm{~cm}$ was determined using diameter tape in two censuses in (1) October-July 2011/12 and (2) October-June 2014/15, i.e. with 3 years in between. For trees with major irregularities (e.g. buttresses) at breast height, the point of measurements (POM) was moved up the stem (max $6.5 \mathrm{~m}$ above ground). The $D$ of these trees was estimated using the taper function by Metcalf et al. (2009):

$D=\frac{D_{h}}{e^{(-\alpha(h-1.30))}}$,

where $\alpha=0.31$, as determined for 31 African tropical species by Ngomanda et al. (2012) and $D_{h}$ is the stem diameter at height, $h$. The height $(H)$ of 930 trees, representing the full $D$ range of the most abundant species in the subset defined above, was measured using a clinometer (Vertex IV, Haglöfs Sweden AB, Långsele, Sweden). To estimate the tree $H$ of all individuals of these species, $H$ vs. $D$ relationships, specific for each species, were established by fitting data to the following function by Lewis et al. (2009):

$H=a\left(1-e^{\left(b\left(D^{c}\right)\right)}\right)$,

where $a, b$ and $c$ are fitting parameters. For all other species, we used generic parameters obtained by fitting Eq. (2) to the data representing all measured trees. Wood density $(\rho)$ of the most abundant tree species was estimated by taking wood cores at breast height by using an increment borer (Haglöf Sweden AB, Långsele, Sweden). The diameter $(5.15 \mathrm{~mm})$ and length (below bark to centre of stem) of the fresh cores and the mass of the oven dried $\left(70^{\circ} \mathrm{C}\right)$ cores were used to calculate the $\rho\left(\mathrm{g} \mathrm{cm}^{-3}\right)$. When presented as plot mean, BA-weighted $\rho$ was used $\left(\rho_{\mathrm{BA}}\right)$. The stem mass (including branches) was estimated using the equation of Chave et al. (2014):
$M_{\text {Stem }}=0.0673\left(\rho D_{\mathrm{BH}}^{2} H\right)^{0.976}$,

where $M_{\text {Stem }}$ is the biomass of individual stems in $\mathrm{kg}$, and $H$ is tree height $(\mathrm{m})$. The coarse root mass $\left(M_{\mathrm{CR}}\right)$ was estimated based on $M_{\text {Stem }}$ using median root to shoot ratio from Cairns et al. (1997) as follows:

$M_{\mathrm{CR}}=0.21 M_{\text {Stem }}$.

To convert biomass into $\mathrm{C}$ mass, we assumed a $\mathrm{C}$ concentration of $47.4 \%$ in line with Martin and Thomas (2011). The net primary production of stems $\left(\mathrm{NPP}_{\mathrm{Stem}}, \mathrm{Mg} \mathrm{ha}^{-1}\right.$ year $^{-1}$ ) was calculated according to the following equation:

$\mathrm{NPP}_{\text {Stem }}=\left(\frac{\sum M_{\text {Stem } 2}-\sum M_{\text {Stem } 1}}{\Delta t}\right) A^{-1}$,

where $\Sigma M_{\text {Stem } 1}$ and $\Sigma M_{\text {Stem } 2}$ is the sum of $M_{\text {Stem }}$ at censuses 1 and 2 in a plot of area A and, $\Delta t$ is the time in between the censuses (2.5 to 3.7 years). Relative growth rate $\left(\mathrm{RGR}_{\text {Stem }}, \%\right.$ year $\left.^{-1}\right)$ is calculated as follows:

$\mathrm{RGR}_{\text {Stem }}=\left(\frac{\ln M_{\text {Stem } 2}-\ln M_{\text {Stem } 1}}{\Delta t}\right) \times 100$

for each individual stem; thereafter $\mathrm{RGR}_{\text {Stem }}$ is averaged for a certain area.

To monitor the stem growth of the two most abundant species $M$. kilimandscharica and S. guineense in detail, dendrometer bands (Jädraås skog och mark, Jädraås, Sweden) were installed at breast height or higher (see $D$ measurements above) on 125 trees of each species. A randomized block design was applied in which $D$ classes $(10 \mathrm{~cm}$ intervals) and plots were used as blocks. The increments were observed approximately every 4 months with calipers. The averages of these readings were used to calculate the annual increment of $M_{\text {Stem }}$ and RGRStem. 
Table 2. Biomass properties and species composition (means \pm SD and range) of all plots (1-15) classified as early (ES; $n=5$ ) or late (LS; $n=5$ ) successional. The data are based on results from the first census (2012) of all stems $\geq 5 \mathrm{~cm}$ within the plots, expect for relative growth rate, recruitment and mortality (Eqs. 6, 10 and 11, respectively) that were based on both census I and II data. The successional indices (based on number of stems, \#, and basal area, BA) were calculated using Eq. (9). The listed species are used to construct the successional index and selected based on their contribution to total stand BA. Diff represents the mean $\%$ differences of LS in relation to ES plots and $P$ values are the results of a $t$ test of the difference between ES and LS. Bold value, $P<0.05$.

\begin{tabular}{|c|c|c|c|c|c|c|}
\hline \multirow[t]{3}{*}{ Plot properties } & \multicolumn{2}{|c|}{ All plots (1-15) } & \multicolumn{4}{|c|}{ Plots of different successional stages } \\
\hline & \multirow[t]{2}{*}{ Mean } & \multirow[t]{2}{*}{ Range } & $\mathrm{ES}(n=5)$ & $\mathrm{LS}(n=5)$ & \multirow[t]{2}{*}{$\operatorname{Diff}(\%)$} & \multirow[t]{2}{*}{$P$ value } \\
\hline & & & Mean SD & Mean SD & & \\
\hline No of stems, $D>5 \mathrm{~cm}_{\left(\mathrm{ha}^{-1}\right)}$ & $752 \pm 398$ & $350-1844$ & $645 \pm 205$ & $868 \pm 563$ & 35 & 0.43 \\
\hline No of stems, $D>10 \mathrm{~cm}\left(\mathrm{ha}^{-1}\right)$ & $453 \pm 218$ & $220-958$ & $421 \pm 134$ & $478 \pm 277$ & 14 & 0.69 \\
\hline Mean cross sect. area, $D>5 \mathrm{~cm}\left(\mathrm{~m}^{-2}\right)$ & $0.047 \pm 0.025$ & $0.023-0.109$ & $0.038 \pm 0.014$ & $0.050 \pm 0.034$ & 33 & 0.47 \\
\hline Mean cross sect. area, $D>10 \mathrm{~cm}\left(\mathrm{~m}^{-2}\right)$ & $0.073 \pm 0.036$ & $0.036-0.158$ & $0.054 \pm 0.018$ & $0.082 \pm 0.046$ & 50 & 0.25 \\
\hline Basal area $\left(\mathrm{BA}, \mathrm{m}^{2} \mathrm{ha}^{-1}\right)$ & $30.0 \pm 11.2$ & $17.6-61.0$ & $22.7 \pm 3.4$ & $36.2 \pm 17.1$ & 59 & 0.12 \\
\hline Mean height, $D>5 \mathrm{~cm}(\mathrm{~m})$ & $14.4 \pm 1.5$ & $12.6-18.5$ & $14.1 \pm 1.2$ & $14.6 \pm 2.4$ & 4 & 0.64 \\
\hline Mean height, $D>10 \mathrm{~cm}(\mathrm{~m})$ & $18.3 \pm 1.7$ & $16.5-22.8$ & $17.5 \pm 0.5$ & $19.0 \pm 2.7$ & 9 & 0.25 \\
\hline Mean $H$ of 100 highest trees ha ${ }^{-1}(\mathrm{~m})$ & $24.6 \pm 3.1$ & $21.7-33.0$ & $22.2 \pm 0.4$ & $26.9 \pm 4.2$ & 21 & 0.040 \\
\hline Number of big trees, $D>40 \mathrm{~cm}\left(\mathrm{ha}^{-1}\right)$ & $54 \pm 36$ & $26-172$ & $39 \pm 14$ & $76 \pm 56$ & 94 & 0.19 \\
\hline No of species & $22.6 \pm 10.8$ & $11.0-49.0$ & $17.0 \pm 3.2$ & $29.2 \pm 14.0$ & 72 & 0.093 \\
\hline Successional index\# & $0.16 \pm 0.15$ & $0.01-0.52$ & $0.03 \pm 0.03$ & $0.33 \pm 0.12$ & 1159 & $<0.001$ \\
\hline Successional index $\mathrm{x}_{\mathrm{BA}}$ & $0.34 \pm 0.28$ & $0.002-0.89$ & $0.03 \pm 0.02$ & $0.65 \pm 0.14$ & 2190 & $<0.001$ \\
\hline \multicolumn{7}{|l|}{ Most abundant species (\% of BA): } \\
\hline Harungana montana (ES) & $2.9 \pm 6$ & $1-22$ & $6.7 \pm 10.0$ & $0.8 \pm 0.9$ & & 0.23 \\
\hline Macaranga kilimandscharica $(\mathrm{ES})$ & $29.0 \pm 27$ & $0-73$ & $59.4 \pm 14.8$ & $3.6 \pm 5.7$ & & $<0.001$ \\
\hline Polyscias fulva (ES) & $3.7 \pm 6$ & $0-16$ & $7.9 \pm 7.2$ & $0.0 \pm 0.1$ & & 0.040 \\
\hline Carapa grandiflora $(\mathrm{LS})$ & $2.5 \pm 3$ & $0-10$ & $0.2 \pm 0.5$ & $3.2 \pm 3.8$ & & 0.13 \\
\hline Cleistanthus polystachyus (LS) & $2.7 \pm 7$ & $3-26$ & $0.0 \pm 0.0$ & $7.4 \pm 11.4$ & & 0.18 \\
\hline Faurea saligna (LS) & $3.2 \pm 10$ & $11-36$ & $0.0 \pm 0.0$ & $9.5 \pm 15.6$ & & 0.21 \\
\hline Ficalhoa laurifolia (LS) & $1.4 \pm 4$ & $0-13$ & $0.1 \pm 0.2$ & $4.0 \pm 5.6$ & & 0.16 \\
\hline Ocotea kenyensis (LS) & $2.9 \pm 3$ & $5-23$ & $4.3 \pm 4.7$ & $0.0 \pm 0.0$ & & 0.07 \\
\hline Ocotea usambarensis (LS) & $3.0 \pm 7$ & $0-9$ & $2.7 \pm 3.7$ & $4.8 \pm 3.2$ & & 0.36 \\
\hline Syzygium guineense (LS) & $25.3 \pm 22$ & $0-65$ & $2.2 \pm 2.3$ & $38.9 \pm 19.0$ & & 0.003 \\
\hline Sum of 10 species ( $\%$ of BA) & $76.6 \pm 15$ & $42-97$ & $83.6 \pm 12.9$ & $72.2 \pm 13.4$ & -14 & 0.21 \\
\hline
\end{tabular}

\subsection{Canopy NPP}

Litter from 90 traps distributed over all plots were collected twice per month from January 2013 to December 2014. In each plot, six of the subplots were randomly assigned one trap that was randomly placed at one of 16 grid points within each subplot using a $5 \times 5 \mathrm{~m}$ grid. The litter traps consisted of nylon mesh bags suspended from a circular wire frame of aluminum $\left(0.3 \mathrm{~m}^{2}\right.$; Jädraås skog och mark, Jädraås, Sweden) and mounted horizontally on wooden poles ca. $0.8 \mathrm{~m}$ aboveground level. The litter from each trap was collected separately, placed in paper bags and sent to the lab where it was oven-dried at $70{ }^{\circ} \mathrm{C}$ to constant mass. After drying, each sample was sorted into five fractions: leaves, reproductive organs (fruits, flowers, seeds), twigs, epiphytes and unidentified fine debris, and weighed. The annual sum of all five fractions was used to calculate the canopy NPP.

\subsection{Fine root, litter and soil organic mass}

Litter and soil were sampled from the centre of each subplot quadrant (480 sample points), where the litter and organic $(\mathrm{O})$ soil were separately excavated from a $0.5 \times 0.5 \mathrm{~m}$ horizontal ground area. Below the O-horizon, three consecutive cores $(8 \mathrm{~cm}$ diameter and $15 \mathrm{~cm}$ depth each) of mineral (M) soil down to a depth of $45 \mathrm{~cm}$ were sampled using a root auger (Ejkelkamp soil \& water, Giesbeek, the Netherlands); thereafter the four M-samples within each subplot and depth were mixed. A subsample of $20 \%$ based on the fresh mass was taken from each O- and mixed M-sample; thereafter roots were extracted from each subsample. All samples were then brought to the lab for drying to constant mass in an oven set to $70^{\circ} \mathrm{C}$. The litter and soil samples were milled in a ball mill (Model: MM 200, Retsch, Germany) and C concentrations were determined by dry combustion using an elemental analyser (Model: EA 1108 CHNS-O, Fisons Instruments, Italy). 


\subsection{Fine-root NPP}

The fine-root production was measured using in-growth cores with root free soil surrounded by mesh containers ( $40 \mathrm{~cm}$ deep, $8 \mathrm{~cm}$ diameter and ca. 2 mesh, i.e. $12 \mathrm{~mm}$ grid). The in-growth cores were installed in the soil by drilling a vertical hole of $8 \mathrm{~cm}$ in diameter to the depth of $40 \mathrm{~cm}$ in the middle of each subplot, using a root auger (see above). The soil from the drilling was separated into the O- and Mhorizons, and after removing the roots it was used to fill the mesh container installed into the drilling pit, maintaining the soil horizons. The in-growth cores were installed in September and December 2013, and fine roots were allowed to grow into the cores over periods of 3-6 months before being harvested in March 2014, July-August 2014, DecemberJanuary 2014/15 and July 2015. To avoid an underestimation of root mass, because a proportion of the roots inevitably remain uncollected (Sierra et al., 2003), this study followed the method by Metcalfe et al. (2007), which controls for systematic underestimation of fine roots. This was conducted by extracting the roots from the soil in the in-growth cores during four $8 \mathrm{~min}$ intervals ( $32 \mathrm{~min}$ ), considering O-and $\mathrm{M}$ horizons separately, and then fitting the cumulative increase of collected root mass over time to the following equation to predict root mass as if the extraction was continued for $120 \mathrm{~min}$ :

$M_{\mathrm{fr}, t}=a \log (t)+b$,

where $M_{\mathrm{fr}, t}$ is the fine-root mass extracted at time $t ; a$ and $b$ are fitting parameters. The roots were brought to the lab and cleaned from soil by rinsing and sedimentation processes in tap water and thereafter dried in $70^{\circ} \mathrm{C}$ until constant mass. The annual sum of production was calculated in proportion to the time between the harvests (without assuming any lagtime) and used as fine-root NPP.

\subsection{Understory}

The understory defined as all above-ground parts of plants with $D<5 \mathrm{~cm}$ (woody, herbaceous and grass species) were sampled from one square metre plot $(1 \times 1 \mathrm{~m})$ randomly placed at one of 16 grid points within each subplot using a $5 \times 5 \mathrm{~m}$ grid. All plants within the one square metre plots were harvested at ground level and thereafter dried in $70^{\circ} \mathrm{C}$ until constant mass, from which the dry mass per area of understory ( $\left.M_{\text {Ustory }}\right)$ was calculated. Based on $M_{\text {Ustory }}$ and $M_{\text {Stem }}$, an understory index (UI) was developed to classify the fraction of understory biomass:

$\mathrm{UI}=\frac{M_{\text {Ustory }}}{\left(M_{\text {Ustory }}+M_{\text {Stem }}\right)}$.

\subsection{Successional index}

A successional index (SI), ranging from 0 to a maximum of 1 , was developed to classify the successional stage of the plots from the fractions of ES and LS trees within the plots:

$\mathrm{SI}_{x}=\frac{\mathrm{LS}_{x}}{T_{x}} \times\left(1-\frac{\mathrm{ES}_{x}}{T_{x}}\right)$,

where $T$ is the plot total. The subscript $x$ denotes whether it is based on basal area (BA) or number of tree individuals (\#). In this study we based the index on the 10 most abundant species representing $77 \%$ of the basal area and $59 \%$ of the individuals of all plots (see Table 2). The classification of which successional group the species belongs to was mainly based on Tesfaye et al. (2002), Fischer and Killman (2008), Bloesch et al. (2009), Kindt et al. (2014) and Rutten et al. (2015a) and we found that three belong to ES and seven to LS (Table 2). Based on SI $\mathrm{BA}_{\mathrm{BA}}$, two groups of five plots each were defined, one with the lowest $(<0.1)$ and one with the highest $\mathrm{SI}_{x}(>0.5)$, denoted ES and LS plots, respectively. Similar ranking and grouping resulted if $\mathrm{SI}_{\#}$ was used instead (Table S1). However, $\mathrm{SI}_{\#}$ values were generally lower since many of the frequently occurring but small trees were not classified for successional groups. The five plots with a $\mathrm{SI}_{x}$ between the ES and LS groups were classified as intermediate or mixed successional plots (MS).

\subsection{Recruitment and mortality}

The recruitment rate $\left(\lambda, \%\right.$ year $\left.^{-1}\right)$ and mortality rate $\left(\mu, \%\right.$ year $\left.^{-1}\right)$ was determined from the number of stems $(>5 \mathrm{~cm} \mathrm{D})$ in census $1\left(n_{0}\right)$, in census $2\left(n_{t}\right)$ and the number of stems that died $\left(D_{t}\right)$ over the time between the two censuses $(t)$. The rates were calculated according to Sheil and May (1996), including a correction factor suggested by Lewis et al. (2004), as follows:

$\lambda=\left[\frac{\ln n_{0}-\ln \left(n_{0}-D_{t}\right)}{t} \times 100\right] \times t^{0.08}$
$\mu=\left[\frac{\ln n_{t}-\ln \left(n_{0}-D_{t}\right)}{t} \times 100\right] \times t^{0.08}$.

\subsection{Statistics}

The significance of the relationship between biomass and production parameters versus the successional indices, understory index, number of big trees and basal area were determined using the regression analysis tool in SigmaPlot 12.5 (Systat Software Inc., San Jose, CA, USA). Differences in forest structure, biomass, $\mathrm{C}$ stock and productivity between ES and LS plots and species were analysed using a two-tailed independent-sample $t$ test. When differences in these parameters between ES, MS and LS plots were analysed, one-way ANOVA was conducted, followed by a post-hoc comparison using Tukey's HSD (honest significant difference) test when the ANOVA indicated a significant difference $(P<0.05)$. Data that violated the assumption of normality, homogeneity or when outliers were present were log-transformed before 

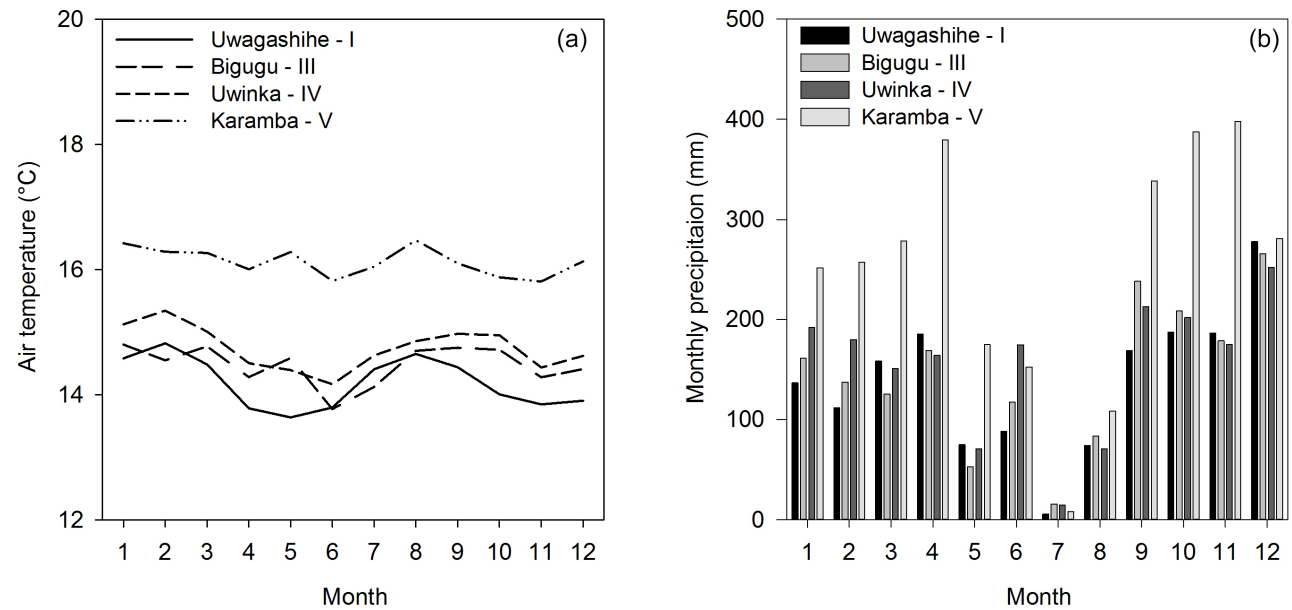

Figure 1. Seasonal variation of monthly mean air temperature (a) and monthly precipitation (b) at four meteorology stations located across a $32 \mathrm{~km}$ east-west transect in Nyungwe tropical montane forest. Roman numbers refer to locations presented in Table 1 . The data are based on half-hourly measurements from July 2013 to June 2015.

the statistical analysis. Both a $t$ test and ANOVA were conducted using SPPS software (IBM SPSS Statistics for Windows, Version 22.0. Armonk, NY: IBM Corp.).

\section{Results}

\subsection{Climate}

The climate was monitored along the transect of plots between July 2013 and June 2015 and was characterized by very small seasonal variations in monthly mean air temperature (ca. $1{ }^{\circ} \mathrm{C}$; Fig. 1a), while the seasonal variation in precipitation exhibited a short dry period in July and less than average precipitation from May to August (Fig. 1b). The annual mean air temperature under the canopies at plots 1 to 12 varied between $13.7 \pm 0.002$ to $14.5 \pm 0.07^{\circ} \mathrm{C}$ and had an annual precipitation of $1657 \pm 163$ to $1860 \pm 116 \mathrm{~mm}$ (Table 1). Plots 13-15 located at ca. $500 \mathrm{~m}$ lower elevation compared to the others had a mean air temperature of $15.5 \pm 0.06^{\circ} \mathrm{C}$ and an annual precipitation of $3016 \pm 63 \mathrm{~mm}$ during the same period. The lowest monthly mean daily minimum temperature varied between 9.9 to $11.7^{\circ} \mathrm{C}$ and the highest monthly mean daily maximum varied between 17.7 to $21.2^{\circ} \mathrm{C}$ among plots. The average temperatures measured at climate stations in nearby open-area plots were on average $0.3{ }^{\circ} \mathrm{C}$ higher than under the canopy. The daily mean soil temperatures were similar to the air temperatures, but with lower mean diurnal amplitudes $\left(1.9^{\circ} \mathrm{C}\right.$ in the soil compared to $6.1^{\circ} \mathrm{C}$ in air). The soil water content at the end of the dry period varied between $0.05-0.1 \mathrm{~m}^{3} \mathrm{~m}^{-3}$ (at $10 \mathrm{~cm}$ depth) while it normally varied between 0.25 $0.4 \mathrm{~m}^{3} \mathrm{~m}^{-3}$ outside the dry period. The daily mean photosynthetic photon flux density at the four meteorology stations was $289 \pm 10 \mu \mathrm{mol} \mathrm{m}^{-2} \mathrm{~s}^{-1}$, with slightly elevated lev- els during the dry period. The 2 years of climate data presented for the transect was similar to the 9-year average from our long-term monitoring station.

\subsection{Successional stage}

The successional index used (SI; Eq. 9) to characterize the differences in successional stages was markedly different between ES and LS plots using both BA (0.03 and 0.65) and the number of stems (\#) per area (0.03 and 0.33 ; Table 2 ) as an index basis. The highest SI in any plot was 0.89 and the reason that the maximum SI (1) was not reached in any of the plots is partly due to the occurrence of some ES species in all plots, but mainly because not all tree species were classified into SI groups. The SI is conservative towards the ES forest type and is sensitive to fact that a high degree of nonclassified species give lower values. The classification into ES and LS groups was used to test for differences in forest structure, $\mathrm{C}$ stock and productivity between stands of different successional stages (Table 2) and in the following, the values reported for the two groups of plots will be separated by an oblique (/) in the order ES/LS.

\subsection{Forest structure}

Many of the common forest structure parameters determined as means for all trees with $D>5 \mathrm{~cm}$ (e.g. stem density, tree cross sectional area at breast height, BA, $H$ ) were generally higher in the LS plots compared to ES plots but the difference was not significant ( $P \geq 0.12$; Table 2). However, the $H$ of the 100 highest trees per ha $(22.2 / 26.9 \mathrm{~m} ; P=0.04)$, indicating the canopy height, and the BA-weighted $\rho$ (ES: 0.48, LS: $\left.0.62 \mathrm{~g} \mathrm{~cm}^{-3}\right), P<0.001$ ) were significantly higher in LS compared to ES plots, with MS plots in between (Table S1). The total number of woody species with $D>5 \mathrm{~cm}$ was 83 

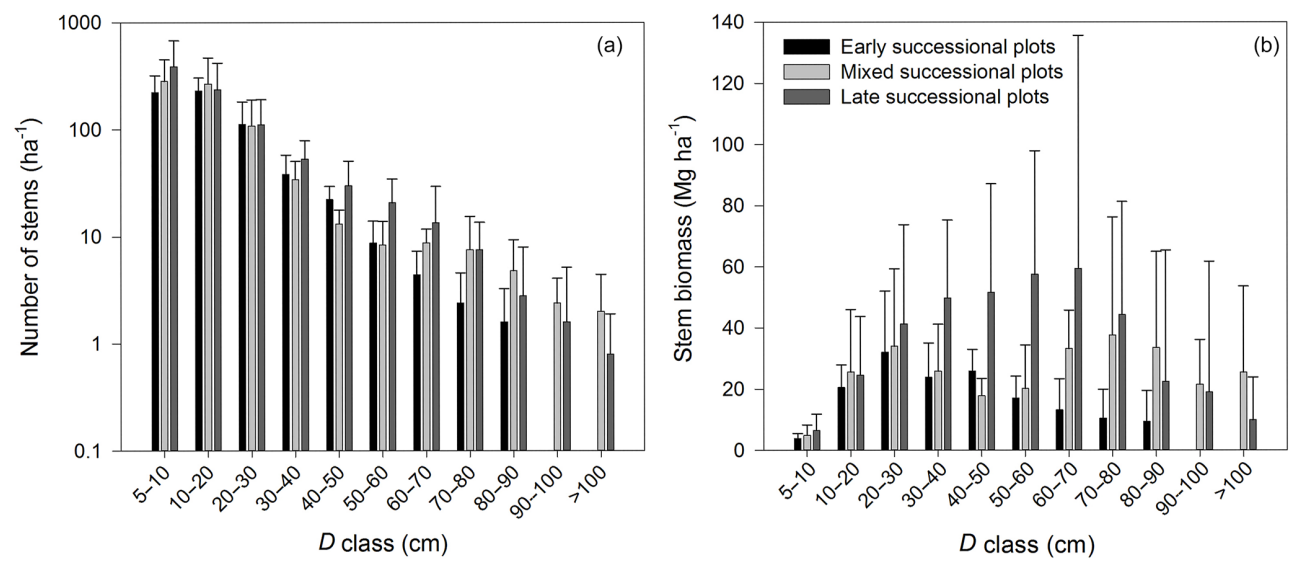

Figure 2. Distribution of the mean stem numbers (a) and stem biomass (b) per unit area in relation to $D$ classes for three groups of plots ( $n=5$ for all groups) belonging to different successional stages. The error bars are standard deviation (SD).

Table 3. Wood density (basal-area-weighted average, $\rho \mathrm{BA}$ ), above-ground biomass (AGB, stems $D \geq 5 \mathrm{~cm}$ ), relative growth rates, recruitment rate and mortality rate of all trees with $D>5 \mathrm{~cm}$, given as means \pm SD and range of all plots (1-15) classified as early (ES; $n=5)$ or late (LS; $n=5$ ) successional. The AGB estimates are based on species-specific or generic $H$ vs. $D$ relationship and $\rho$. Bold value, $P<0.05$.

\begin{tabular}{|c|c|c|c|c|c|c|}
\hline \multirow[t]{3}{*}{ Plot properties } & \multicolumn{2}{|c|}{ All plots $(1-15)$} & \multicolumn{4}{|c|}{ Plots of different successional stages } \\
\hline & \multirow[t]{2}{*}{ Mean } & \multirow[t]{2}{*}{ Range } & $\mathrm{ES}(n=5)$ & $\mathrm{LS}(n=5)$ & \multirow[t]{2}{*}{ Diff $(\%)$} & \multirow[t]{2}{*}{$P$ value } \\
\hline & & & Mean SD & Mean SD & & \\
\hline Wood density, specific $\left(\rho_{\mathrm{BA}}, \mathrm{g} \mathrm{cm}^{-1}\right)$ & $0.56 \pm 0.06$ & $0.47-0.66$ & $0.48 \pm 0.02$ & $0.62 \pm 0.02$ & 29 & $<0.001$ \\
\hline AGB, specific $H$ and $\rho\left(\mathrm{Mgha}^{-1}\right)$ & $274 \pm 165$ & $142-793$ & $156 \pm 15$ & $387 \pm 244$ & 147 & 0.022 \\
\hline AGB, generic $H$, specific $\rho\left(\mathrm{Mg} \mathrm{ha}^{-1}\right)$ & $275 \pm 151$ & $148-743$ & $164 \pm 17$ & $374 \pm 222$ & 128 & 0.023 \\
\hline AGB, specific $H$, generic $\rho\left(\mathrm{Mg} \mathrm{ha}^{-1}\right)$ & $279 \pm 136$ & $156-699$ & $189 \pm 24$ & $357 \pm 209$ & 89 & 0.080 \\
\hline AGB, generic $H$ and $\rho\left(\mathrm{Mg} \mathrm{ha}^{-1}\right)$ & $275 \pm 125$ & $161-650$ & $191 \pm 30$ & $342 \pm 189$ & 79 & 0.083 \\
\hline Relative growth rate $\left(\%\right.$, year $\left.^{-1}\right)$ & $5.2 \pm 2.0$ & $2.1-10.0$ & $6.8 \pm 1.9$ & $3.8 \pm 1.4$ & -44 & 0.022 \\
\hline Recruitment rate $\left(\%\right.$, year $\left.^{-1}\right)$ & $3.8 \pm 3.4$ & $0.4-14.1$ & $6.3 \pm 4.4$ & $1.4 \pm 1.0$ & -77 & 0.007 \\
\hline Mortality rate $\left(\%\right.$, year $\left.^{-1}\right)$ & $1.4 \pm 0.5$ & $0.5-2.7$ & $1.1 \pm 0.4$ & $1.4 \pm 0.4$ & 26 & 0.26 \\
\hline
\end{tabular}

(Table S2), with an average of 23 per plot and no significant difference between ES and LS plots $(17 / 29, P=0.093)$. However, the abundance based on BA of several species was substantially different, but significantly so only in a few cases due to large variation in species composition between plots also within successional groups (Table 2).

The distribution of stem number across $D$ classes in all forest types described an exponential decay function with increasing $D$ and thus decreased linearly when a logarithmic scale for stem numbers was applied (Fig. 2a). Notably, ES plots were lacking stems in $D$ classes $>90 \mathrm{~cm}$. Generally, trees with $D$ of 5 to $10 \mathrm{~cm}$ had a small contribution to the total biomass ( $<2.5 \%$; Fig. $2 \mathrm{~b})$. The distribution of biomass across $D$ classes differed between ES and LS plots, with a major part of stand biomass in relatively small size trees in ES plots $(68 \%$ in trees $<50 \mathrm{~cm} D)$ and large size trees in MS and LS plots ( $>50 \%$ in trees $>50 \mathrm{~cm} D$; Fig. $2 \mathrm{~b}$ ). Thus the tree demography varied between ES and LS stands, reflecting a difference in disturbance history.

\subsection{Biomass and $\mathrm{C}$ stock}

The above-ground $\mathrm{C}$ pool of trees was estimated from $D$ measurements of all stems, $H$ measurements of 930 trees of different $D$ classes from the most abundant species and species-specific $\rho$ obtained from measurements (species representing $91.2 \%$ of the BA) or databases (Tables S2 and S3). The $H$ measurements were used to determine both generic (based on all measured trees in this study, i.e. site specific) and species-specific parameterizations of Eq. (2) (Fig. 3). Both the measured data and the generic parameterization clearly show that the $H$ to $D$ ratio was lower in this montane forest compared to a generic equation for the central African lowland (Fig. 3a). The output from the species-specific parameterization show that ES compared to LS species had a significantly lower $H$ at $D$ of $40(-10 \%, P=0.033)$ and $80 \mathrm{~cm}(-21 \%, P=0.020)$ (Fig. $3 \mathrm{~b}$ and c). Furthermore, the average $\rho$ of ES compared to LS species was $19 \%$ lower, but the difference was only marginally significant $(P=0.057)$ for the 10 most abundant species. However, the BA-weighted 
Table 4. Carbon stocks of different ecosystem compartments (means \pm SD and plot range) for all plots (1-15) classified as early (ES, $n=5)$ and late (LS, $n=5$ ) successional. Diff and $P$ value represent the mean differences and the results of a $t$ test of the difference between ES and LS, respectively. For calculating carbon stock (C stock) in the different compartments we used measured values for each fraction of litter $(37.3-51.3 \% \mathrm{C})$, organic soil $(26.0-49.6 \% \mathrm{C})$, mineral soil $(1.3-9.9 \% \mathrm{C})$ and literature values for wood (47.4\% C, Martin and Thomas,

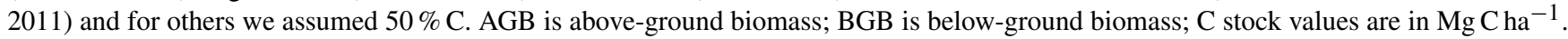
Bold value, $P<0.05$.

\begin{tabular}{|c|c|c|c|c|c|c|}
\hline \multirow[t]{3}{*}{ Compartment } & \multicolumn{2}{|c|}{ All plots $(1-15)$} & \multicolumn{4}{|c|}{ Plots of different successional stages } \\
\hline & \multirow[t]{2}{*}{ Mean } & \multirow[t]{2}{*}{ Range } & $\mathrm{ES}(n=5)$ & $\mathrm{LS}(n=5)$ & \multirow[t]{2}{*}{ Diff $(\%)$} & \multirow[t]{2}{*}{$P$ value } \\
\hline & & & Mean SD & Mean SD & & \\
\hline C stockstem & $130 \pm 78$ & $68-376$ & $74 \pm 7.3$ & $183 \pm 116$ & 146 & $\mathbf{0 . 0 2 3}$ \\
\hline C stock ${ }_{\text {Understory }}^{*}$ & $2.0 \pm 1.3$ & $0.2-5.4$ & $1.7 \pm 0.6$ & $1.9 \pm 1.2$ & 11 & 0.98 \\
\hline C stock $\mathrm{AGB}$ & $132 \pm 78$ & $69.4-377$ & $76 \pm 7.2$ & $185 \pm 115$ & 143 & 0.021 \\
\hline C stock Coarse roots $_{\text {. }}$ & $27 \pm 16$ & $14.2-79$ & $16 \pm 2$ & $38 \pm 24$ & 146 & $\mathbf{0 . 0 2 3}$ \\
\hline $\mathrm{C}$ stock $_{\text {Fine roots }}$ & $3.3 \pm 1.7$ & $2.0-8.1$ & $2.8 \pm 0.5$ & $3.8 \pm 1.4$ & 37 & 0.17 \\
\hline C stock $\mathrm{BGB}$ & $31 \pm 17$ & $17.5-83$ & $18 \pm 1.3$ & $42 \pm 25$ & 130 & 0.025 \\
\hline C stock Litter & $4.3 \pm 1.4$ & $1.6-6.3$ & $4.8 \pm 1.0$ & $3.5 \pm 1.6$ & -28 & 0.15 \\
\hline C stock Organic soil & $31 \pm 13$ & $9-51$ & $26 \pm 7$ & $36 \pm 15$ & 35 & 0.34 \\
\hline C stock Mineral soil & $157 \pm 37$ & $86-196$ & $173 \pm 13$ & $139 \pm 45$ & -20 & 0.13 \\
\hline C stock Soil tot & $192 \pm 45$ & $97-252$ & $204 \pm 13$ & $178 \pm 56$ & -13 & 0.27 \\
\hline C stock ${ }_{\text {Total }}$ & $353 \pm 99$ & $232-662$ & $299 \pm 21$ & $402 \pm 147$ & 35 & 0.11 \\
\hline AGB fraction of C stock $\mathrm{Total}(\%)$ & $36 \pm 12$ & $23-57$ & $25 \pm 0.8$ & $44 \pm 14$ & 73 & 0.019 \\
\hline $\mathrm{AGB}+\mathrm{BGB}$ fraction of $\mathrm{C}$ stock $_{\text {Total }}(\%)$ & $44 \pm 14$ & $28-68$ & $32 \pm 1.0$ & $54 \pm 17$ & 70 & 0.019 \\
\hline
\end{tabular}

* Understory data are from Ndayisabye (2014).
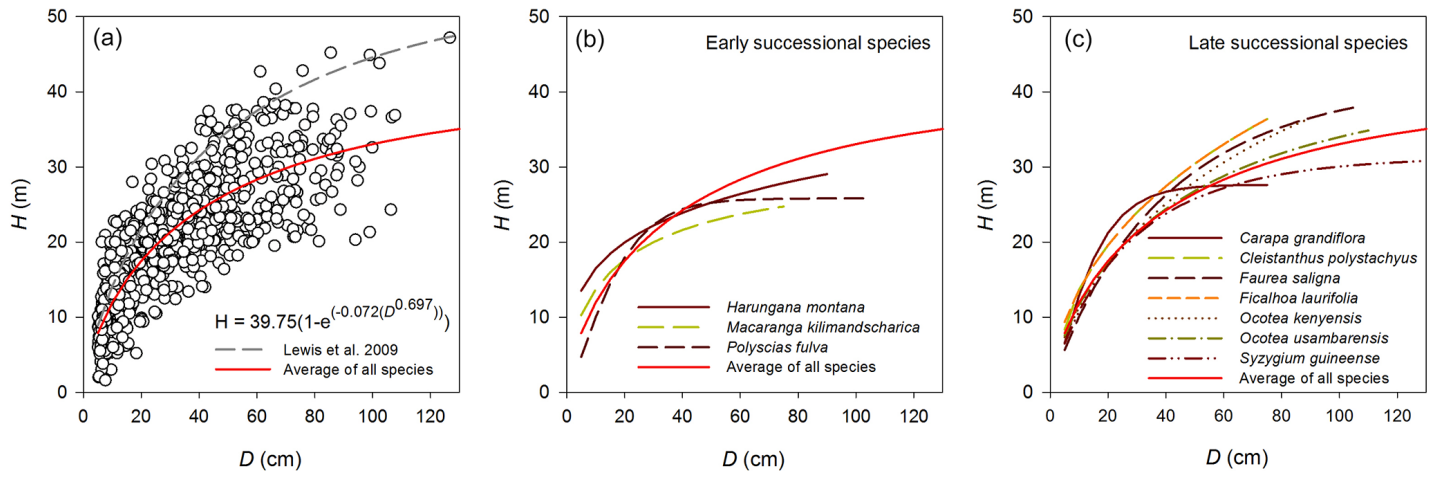

Figure 3. Height $(H)$ vs. stem diameter at breast height $D$ relationship for 930 trees representing the 25 most abundant species of all plots and fitted to Eq. (2). The relationship for all measurements (red line) is compared to the measurements of 1982 trees in African tropical forests (Lewis et al 2009, grey dashed line) mainly at an altitude below $1000 \mathrm{~m}$ a.s.l. (a) as well as to species-specific functions for the 10 most abundant species, including (b) three early successional species (ES) and (c) seven late successional species (LS). All species-specific data are presented in Table S3. The mean simulated height $(\mathrm{m})$ at $D=10 \mathrm{~cm}$ was $13.4 \pm 3.3$ in ES and $12.0 \pm 1.4$ in LS $(P=0.35) ; D=40 \mathrm{~cm}$ was $23.3 \pm 1.5$ in $\mathrm{ES}$ and $25.9 \pm 1.5$ in $\operatorname{LS}(P=0.033) ; D=80 \mathrm{~cm}$ was $26.4 \pm 1.7$ in $\mathrm{ES}$ and $33.4 \pm 3.9$ in $\operatorname{LS}(P=0.020)$.

$\rho$ of LS compared to ES plots was $29 \%$ higher $(P<0.001$; Table 3). The use of species specific rather than generic $H$ vs. $D$ relationships and $\rho$ values did, as expected, not change the estimated average stem biomass across all plots $\left(274 \mathrm{Mg} \mathrm{ha}^{-1}\right)$ but had a large effect on the estimated difference in stem biomass between ES and LS plots (Table S1). Using the species-specific parameters resulted in a higher stem biomass of $146 \%$ in LS compared to ES plots $\left(156 / 387 \mathrm{Mg} \mathrm{ha}^{-1}, P=0.022\right)$ while the generic parameters suggested only a $79 \%$ difference $\left(191 / 342 \mathrm{Mg} \mathrm{ha}^{-1}\right.$,
$P=0.083)$. The stem biomass of the MS plots was always in between ES and LS plots and was significantly different from ES, but not LS (Table S1).

The total above- and below-ground $\mathrm{C}$ pools (down to a depth of $45 \mathrm{~cm}$ in the mineral soil, excluding standing and fallen dead wood) averaged to $353 \pm 138 \mathrm{MgCha}^{-1}$ across all plots, with a non-significant difference between ES and LS pools $\left(299 / 402 \mathrm{Mg} \mathrm{Cha}^{-1}, P=0.11\right.$; Table 4). However, the relationships of $\mathrm{C}$ stock $\mathrm{Stem}_{\mathrm{St}}$ with $\mathrm{SI}_{\mathrm{BA}}$ $\left(R^{2}=0.67\right.$; Fig. 5a) and $\mathrm{SI}_{\#}\left(R^{2}=0.42\right.$; Fig. S2 $)$ were 

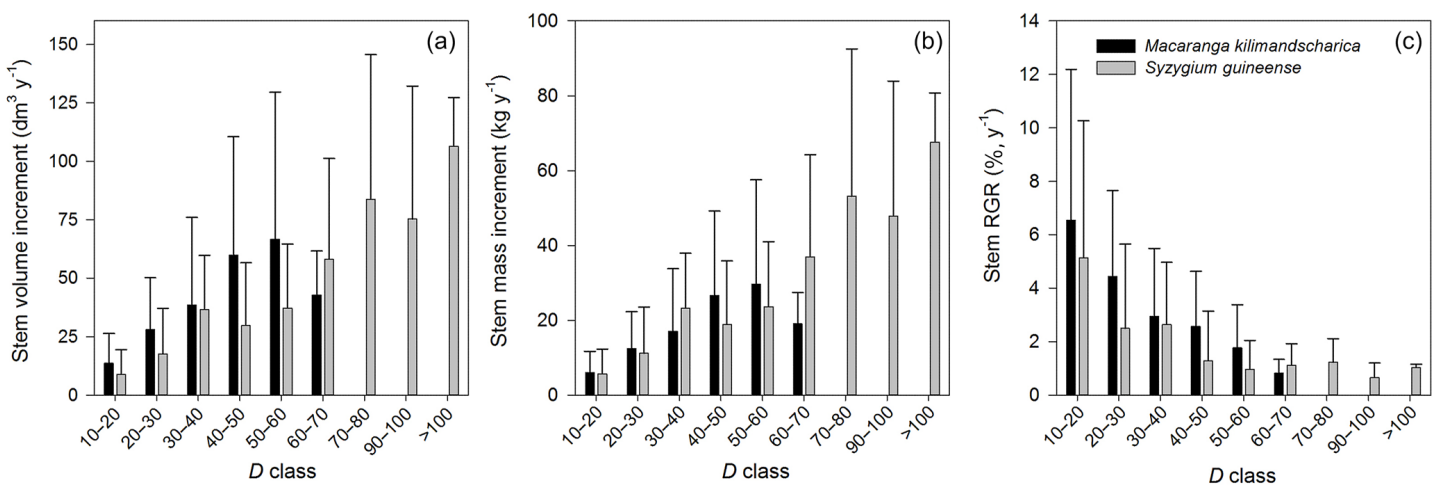

Figure 4. Annual stem volume increment (a), mass increment (b) and relative growth rate (c) for M. kilimandscharica ( $n=112)$ and $S$. guineense $(n=119)$ distributed over all available $D$ classes and all plots. Stem production estimates are based on nine consecutive recordings over 3 years of $D$ with fixed dendrometer bands. The volume increment, mass increment and relative growth rate (RGR) of stems averaged over the six lowest $D$ classes $(10$ to $70 \mathrm{~cm})$ were $53 \%(P=0.012), 6 \%(P=0.62)$ and $35 \%(P=0.027)$ larger for M. kilimandscharica compared to $S$. guineense. Mean weighted values based on $D$ classes were used in the comparison.

both highly significant $(P<0.001)$. The woody $\mathrm{C}$ pools were significantly different between ES and LS plots (C stock $_{\text {Stem }} 74 / 183 \mathrm{Mg} \mathrm{Cha}^{-1}, P=0.023$; C stock CoarseRoots $16 / 35 \mathrm{MgC} \mathrm{ha}^{-1}, P=0.031$ ), as were AGB (including understory), BGB (including fine roots) and the ratio of $\mathrm{AGB}$ to total $\mathrm{C}(25 / 44 \%, P=0.019$; Table 4$)$ and total biomass $(\mathrm{AGB}+\mathrm{BGB})$ to total stand $\mathrm{C}(32 / 54 \%, P=0.020)$. The $\mathrm{C}$ stockstem was negatively and positively related to understory index (Eq. 8) and the number (\#) of large trees (Fig. 6a, b), respectively, although none of these parameters significantly differed between plots belonging to the two successional groups.

The total C stock of litter, organic soil and mineral soil were similar in the plots of the two successional groups (204/178 $\mathrm{Mg} \mathrm{Cha}^{-1}, P=0.27$; Table 4). The depth of the soil organic layer was on average $11 \mathrm{~cm}$ (range: $4.5-17.4 \mathrm{~cm}$ ) with no significant difference between ES and LS plots $(P=$ 0.57). Despite the relatively thick organic layer and high $C$ concentration (26-50\%), the C Stock OrganicSoil was relatively low $\left(26 / 36 \mathrm{MgC} \mathrm{ha}^{-1}, P=0.34\right)$ because of a very low bulk density $\left(0.08 \mathrm{~g} \mathrm{~cm}^{-3}\right)$ as the organic soil horizon mainly consisted of a soft matrix of fine roots and decaying litter.

\subsection{NPP, RGR, mortality and recruitment}

The sum of NPP of different forest compartments (NPP $\left.{ }_{\text {Tot }}\right)$ was on average $9.41 \pm 1.50 \mathrm{MgCha}^{-1}$ year $^{-1}$ across all plots (Table 5). The variation between plots ranged from 6.7 to $12.1 \mathrm{Mg} \mathrm{Cha}^{-1}$ year $^{-1}$, but no difference between ES and LS plots was observed (9.3/9.2 $\mathrm{MgC} \mathrm{ha}^{-1}$ year $^{-1}, P=$ 0.93). The ratios of $\mathrm{NPP}_{\text {wood }}, \mathrm{NPP}_{\text {FineRoots }}$ and $\mathrm{NPP}_{\text {Canopy }}$ to $\mathrm{NPP}_{\text {Total }}$ were on average $0.39,0.21$ and 0.40 , and did not significantly differ between ES and LS plots $(P>0.32)$. $\mathrm{NPP}_{\text {Stem }}$ was related neither to $\mathrm{SI}_{\mathrm{BA}}\left(R^{2}<0.01 ;\right.$ Fig. 5) nor to $\mathrm{SI}_{\#}\left(R^{2}=0.04\right.$; Fig. S2). However, $\mathrm{RGR}_{\text {Stem }}$ was negatively related to both $\mathrm{SI}_{\mathrm{BA}}\left(R^{2}=0.27, P=0.048\right.$; Fig. 5) and $\mathrm{SI}_{\#}\left(R^{2}=0.52, P=0.003\right.$; Fig. S2), and $\mathrm{RGR}_{\text {Stem }}$ was $79 \%$ higher in ES compared to LS plots $\left(6.8 / 3.8 \%\right.$, year ${ }^{-1}$, $P=0.022$; Table 3) and in between in MS plots (Table S1).

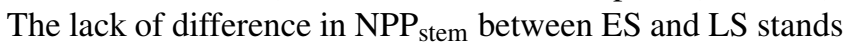
is probably the net result of counteracting effects of differences in stem biomass (higher in LS stands) and RGR $_{\text {stem }}$ (higher in ES stands).

To explore how production and RGR varied with tree sizes, the growth of the most abundant ES and LS species $(M$. kilimanscharica and $S$. guineense, respectively) were analysed in detail using dendrometer band readings over 3 years (Fig. 4). The stem volume increment and $\mathrm{RGR}_{\text {Stem }}$ were significantly higher $(P=0.012$ and 0.027$)$ in $M$. kilimanscharica than in $S$. guineense within the $D$ range of $10-70 \mathrm{~cm}$. However, the stem mass production did not differ between the two species ( $P=0.62$; Fig. 4) since M. kilimanscharica had lower $\rho$ than $S$. guineense (0.44 and 0.63). Speciesspecific tree growth within given $D$ classes did not significantly vary among plots or along the plot transect (data not shown), indicating that the species-specific responses were not constrained by changes in the plot environment.

The annual recruitment of new stems $(6.3 / 1.4 \%, P=$ $0.007)$ was significantly higher in ES compared to LS plots, while the annual mortality $(1.1 / 1.4 \%, P=0.26)$ was similar in both successional groups (Table 3). However, the most dominant ES species M. kilimandscharica had significantly higher annual mortality compared to the most dominant LS species $S$. guineense $(2.1 / 0.63 \%, P=0.035)$ at plots $(n=8)$ where they co-occurred $(\geq 10$ stems of each). However, recruitment rate $(3.0 / 1.4 \%, P=0.17)$ did not significantly differ between these two species on plots where they co-occurred. 

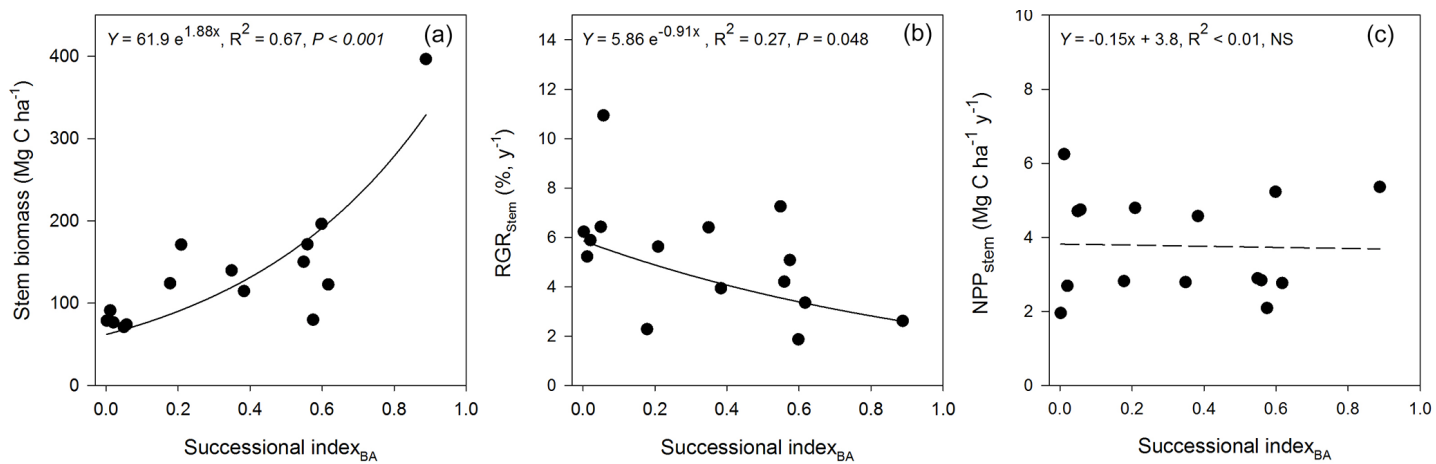

Figure 5. Biomass (a), relative growth rates (RGR) (b) and net primary production (NPP) (c) of stems including branches of each plot in relation to its successional index, based on basal area (BA) of most abundant early and late successional tree species (Eq. 10). Biomass, RGR and NPP are based on C units and calculated from Eqs. (3), (6), (5), respectively, based on measurements of $D_{\mathrm{BH}}$, height, wood density and a stem tissue $\mathrm{C}$ concentration of $47.4 \%$. The adjusted $R^{2}$ values are 0.65 and 0.21 in (a, b).

Table 5. Net primary production (NPP, Eq. 5) of different forest compartments (means \pm SD and range) for all plots (1-15) classified as early (ES, $n=5$ ) and late (LS, $n=5$ ) successional. Diff and $P$ value represent the mean differences and the results of $t$ test of the difference between ES and LS, respectively. For C concentrations of different compartments see Table 4. NPP values are in $\mathrm{MgCha}^{-1} \mathrm{year}^{-1}$. OL, organic soil layer; ML, mineral soil layer.

\begin{tabular}{|c|c|c|c|c|c|c|}
\hline \multirow{3}{*}{ Compartment } & \multicolumn{2}{|c|}{ All plots $(1-15)$} & \multicolumn{4}{|c|}{ Plots of different successional stages } \\
\hline & \multirow[t]{2}{*}{ Mean } & \multirow[t]{2}{*}{ Range } & $\mathrm{ES}(n=5)$ & $\mathrm{LS}(n=5)$ & \multirow{2}{*}{$\operatorname{Diff}(\%)$} & \multirow{2}{*}{$P$ value } \\
\hline & & & Mean SD & Mean SD & & \\
\hline $\mathrm{NPP}_{\text {Stem }}$ & $2.8 \pm 1.0$ & $1.6-4.5$ & $3.0 \pm 1.2$ & $2.7 \pm 1.1$ & -12 & 0.61 \\
\hline NPP $_{\text {CoarseRoots }}$ & $0.9 \pm 0.4$ & $0.5-1.5$ & $1.0 \pm 0.4$ & $0.9 \pm 0.5$ & -4 & 0.89 \\
\hline $\mathrm{NPP}_{\text {Wood }}(\mathrm{AG} \& \mathrm{BG})$ & $3.7 \pm 1.3$ & $2.0-6.0$ & $4.0 \pm 1.6$ & $3.6 \pm 1.5$ & -10 & 0.68 \\
\hline $\mathrm{NPP}_{\text {FineRoot }}(\mathrm{OL})$ & $1.2 \pm 0.4$ & $0.8-1.9$ & $1.2 \pm 0.2$ & $1.1 \pm 0.4$ & -10 & 0.51 \\
\hline $\mathrm{NPP}_{\text {FineRoot }}(\mathrm{ML})$ & $0.8 \pm 0.3$ & $0.2-1.2$ & $0.8 \pm 0.2$ & $0.7 \pm 0.4$ & -19 & 0.41 \\
\hline $\mathrm{NPP}_{\text {FineRoots }}$ & $2.0 \pm 0.6$ & $1.2-2.9$ & $2.0 \pm 0.4$ & $1.7 \pm 0.7$ & -14 & 0.43 \\
\hline $\mathrm{NPP}_{\text {Leaves }}$ & $2.4 \pm 0.6$ & $1.5-3.4$ & $2.3 \pm 0.4$ & $2.4 \pm 0.7$ & 5 & 0.77 \\
\hline $\mathrm{NPP}_{\text {Reproductive }}$ & $0.5 \pm 0.4$ & $0.2-1.6$ & $0.3 \pm 0.1$ & $0.6 \pm 0.5$ & 63 & 0.38 \\
\hline $\mathrm{NPP}_{\text {Twigs }}$ & $0.5 \pm 0.2$ & $0.2-1.0$ & $0.4 \pm 0.1$ & $0.6 \pm 0.3$ & 39 & 0.25 \\
\hline $\mathrm{NPP}_{\text {Epiphytes }}$ & $0.2 \pm 0.3$ & $0.01-1.0$ & $0.2 \pm 0.3$ & $0.3 \pm 0.4$ & 73 & 0.58 \\
\hline $\mathrm{NPP}_{\text {Other }}$ & $0.04 \pm 0.04$ & $0.02-0.2$ & $0.1 \pm 0.1$ & $0.03 \pm 0.01$ & -52 & 0.35 \\
\hline $\mathrm{NPP}_{\text {Canopy }}$ & $3.7 \pm 0.9$ & $2.2-5.6$ & $3.3 \pm 0.4$ & $3.9 \pm 1.3$ & 18 & 0.35 \\
\hline $\mathrm{NPP}_{\mathrm{Tot}}$ & $9.4 \pm 1.5$ & $6.7-12.1$ & $9.3 \pm 1.7$ & $9.2 \pm 2.1$ & -1 & 0.93 \\
\hline $\mathrm{NPP}_{\text {Wood }} / \mathrm{NPP}_{\text {Tot }}(\%)$ & $39 \pm 10$ & $23-51$ & $41.9 \pm 10.9$ & $38.2 \pm 9.9$ & -9 & 0.59 \\
\hline $\mathrm{NPP}_{\text {FineRoots }} / \mathrm{NPP}_{\text {Tot }}(\%)$ & $21 \pm 6$ & $11-32$ & $22.3 \pm 5.9$ & $19.4 \pm 6.7$ & -13 & 0.48 \\
\hline $\mathrm{NPP}_{\text {Canopy }} / \mathrm{NPP}_{\text {Tot }}(\%)$ & $40 \pm 102$ & $29-59$ & $35.8 \pm 5.7$ & $42.4 \pm 12.7$ & 18 & 0.32 \\
\hline
\end{tabular}

\section{Discussion}

Here, we report the first comprehensive estimates of the productivity, biomass and $\mathrm{C}$ stocks of African TMFs. We generally found high $\mathrm{C}$ stocks and productivity, with higher AGB at later stages compared to early successional forests, but similar productivity across different successional stages. Our results further demonstrated that accurate quantification of the $\mathrm{C}$ stocks and dynamics of the forests in the present study required local information on tree allometry, wood density and species composition. This highlights the need to account for such variation in traits when estimating $\mathrm{C}$ stocks of tropi- cal rainforests at different successional stages and in different regions, as well as when implementing REDD+ projects.

\subsection{Biomass and $\mathrm{C}$ stocks in relation to successional status}

While ES forest stands with a closed canopy and mature trees had significantly lower AGB and BGB (59\%, $P=0.023$ and $52 \%, P=0.025)$ than LS stands, there were no significant differences observed for the soil $\mathrm{C}$ stock (Table 4). As a consequence, the plant (AGB + BGB) fractions of the total $\mathrm{C}$ stock was significantly lower in ES compared to LS plots (32\% in ES, $54 \%$ in LS; $P=0.020$ ). This finding is in 

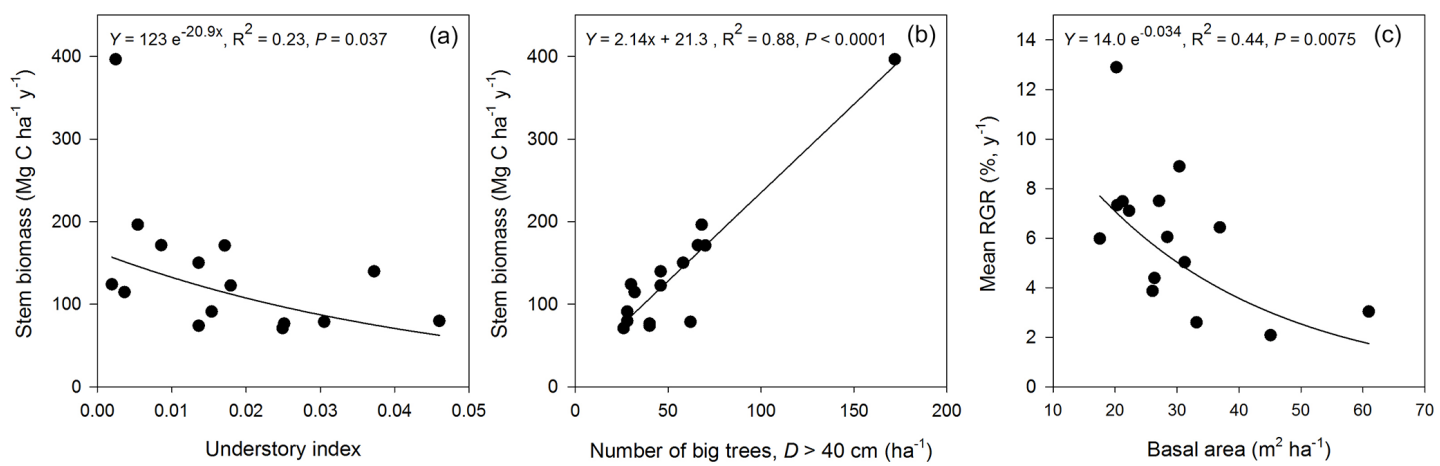

Figure 6. Biomass of stems including branches in relation to understory index (a), number of big trees with $D>40 \mathrm{~cm}(\mathbf{b})$ and mean relative growth rates (RGR) of stems in relation basal area (BA). Understory index is calculated from Eq. (8) and biomass and RGR are expressed in $\mathrm{C}$ units and calculated from Eqs. (3) and (6), respectively, based on measurements of $D, H$ and $\rho$ and a stem tissue C concentration of $47.4 \%$. The correlation of stem biomass vs. number of big trees (b) is also significant when the extreme value is omitted $(P=0.004)$. The adjusted $R^{2}$ values are 0.17 and 0.39 in $(\mathbf{a}, \mathbf{c})$.

line with other studies reporting relatively unaffected soil C stocks in moderately disturbed and secondary tropical forest (Martin et al., 2013), although disturbances may have significant effects on the soil C stock in steep slopes and thus more severely affect TMFs. As shown by the significant relationship between the stem biomass and the successional index $\left(\mathrm{SI}_{x}\right)$ based on BA or stem density (Figs. 5a and S2a), the difference in AGB is connected to the species composition of both ES and LS forest stands. The larger AGB in LS compared to ES forest stands was due to LS tree species having significantly higher $\rho$ and $H$ to $D$ ratio at a given stem diameter (in the larger diameter classes; Fig. 3; Table 3; see Sect. 4.3), as well as LS stands having a larger fraction of large trees than ES stands (Figs. 2, 6b). The basal area actually did not significantly differ between ES and LS stands. Our results agree with earlier studies showing that information on the abundance of large trees is an important indicator and determinant of the whole forest stand AGB (Slik et al., 2013; Bastin et al., 2015). In summary, our data support hypothesis \#1 "Tree biomass and total C stock is higher in LS compared to ES stands".

\subsection{Productivity and $\mathrm{C}$ dynamics}

Our results are in line with the general observation that ES species grow faster than LS species (Poorter et al., 2008; Gustafsson et al., 2016) since we observed a $53 \%$ higher $\mathrm{RGR}_{\text {Stem }}(P=0.012)$ of the dominant ES species (M. kilimandscharica) compared with the dominant LS species ( $S$. guineense) over a wide range of $D$ classes. Furthermore, this was expressed at the plot level as the average $\mathrm{RGR}_{\text {Stem }}$ in ES plots was twice as high as in LS plots $(P=0.017)$. In spite of the higher average RGR $_{\text {Stem }}$ in ES compared to LS species/plots, we observed no significant differences in NPP of any compartment (wood, canopy, fine roots; Table 5) between ES and LS plots. There are likely two reasons for this apparent discrepancy: firstly the counterbalancing effects of differences in AGB (higher in LS) and RGR Stem $_{\text {(higher in }}$ ES) on NPP, and secondly the larger number of big trees (with lower RGRStem; Fig. 4c) in the LS compared to the ES plots (Fig. 2a, b). Thus, we find support for hypothesis \#2: "trees in ES stands are smaller but have higher relative growth rates compared to trees in LS stands, resulting in similar NPP at both successional stages".

It is generally thought that the productivity of highelevation rainforests is low, likely due to low temperature and radiation (i.e. increased cloudiness; Bruijnzeel and Veneklaas, 1998). Indeed, productivity declines with increasing elevation have been reported from Borneo and the Andes (Kitayama and Aiba, 2002; Girardin et al., 2010), as well as in a compilation of NPP data from different continents and elevations (Malhi et al., 2011). However, the TMF of the present study has high productivity. Both the aboveground and total NPP of this study were only slightly lower $(-7$ and $-17 \%)$ than the average recorded NPP for lowland $(<1000 \mathrm{~m}$ a.s.1.) tropical forests (Malhi et al., 2011). When compared with studies at elevations and mean annual temperatures similar to in our study, the Nyungwe TMF had among the highest NPP values estimated for TMFs. Fehse et al. (2002) also reported high above-ground biomass production of secondary tropical TMFs, although it was not expressed as NPP and therefore difficult to compare. Our values on canopy and stem NPP were similar to what was found in a lower montane forest (1050 m a.s.l.) in south-east Asia (Hertel et al., 2009), while our fine-root NPP was approximately twice as high as in that study. However, our values of stem and canopy NPP were much higher compared to a study by Girardin et al. (2010) in the Andes at a similar elevation to our study, while values of fine-root NPP did not differ.

\subsection{Stem allometry and wood density}

Parameterization of equations to establish $H$ vs. $D$ relationships developed from data obtained from outside the study 
area causes large uncertainties in $\mathrm{C}$ stock estimation of tropical forests (Feldpausch et al., 2011; Kearsley et al., 2013). Indeed, we found significant differences in $\mathrm{C}$ stock estimates when using species-specific parameters compared to generic parameters (the mean across all species) of $\rho$ and $H$ to $D$ relationship (Table 3 ; Fig. 3 ). In particular, the use of species-specific parameters greatly affected the comparison of $\mathrm{C}$ stocks of LS and ES stands. The stem $\mathrm{C}$ stock was $147 \%$ higher in LS compared to ES forest stands using local and species-specific parameters, while the difference was reduced to $79 \%$ if generic parameters were used (Table 3). With species-specific parameters the difference was significant $(P=0.021)$, while it was not if generic parameters were used $(P=0.083)$. The main reasons for this discrepancy were that LS tree species had a considerably higher $\rho$ and $H$ vs. $D$ relationship (in larger size classes) compared to ES tree species (Table 3; Fig. 3). These results demonstrated that species composition, together with differences in $\rho$ and allometry between LS and ES tree species, are important drivers for the difference in $\mathrm{C}$ stocks between primary and secondary forests.

Our results further showed that the application of lowland $H$ vs. $D$ relationships (Fig. 3a; lowland parameterization of Eq. 2; Lewis et al., 2009) for our TMF caused considerable overestimation of $\mathrm{C}$ stocks (Fig. 3a) as it provided strongly overestimated $H$ for our study area. Thus, our results demonstrate the importance of using locally derived or validated $H$ vs. $D$ relationships in TMF C stock estimation, as previously also shown in mixed secondary forests of Indonesia (Ketterings et al., 2001).

In the high tree diameter range, we found that LS trees were significantly taller than ES trees at a given tree diameter, while it was the opposite in the low tree diameter range (Fig. 3b, c). ES forest stands are characterized by pioneers, with low stature and light wood (Swaine and Whitmore, 1988; Muller-Landau, 2004). For example, the dominant ES species $M$. kilimandscharica $(59.4 \pm 14.8 \%$ of BA in ES plots; Table 2) rarely grows taller than $25 \mathrm{~m}$ (Fig. 3c). Such differences between ES and LS species have been observed earlier (e.g. King, 1996) and may reflect a trade-off between fast height extension and mechanical stability during forest succession (Lawton, 1984). ES species have faster height growth in the beginning of successional progression but will eventually be surpassed by LS trees with higher $\rho$ and stability.

High relative growth rates and low $\rho$ of ES tree species agree with the plant economics spectrum of fast-growing species (Woodall et al., 2015; Reich, 2014). The trade-off between $\rho$ and growth rates has also been observed in earlier tropical studies (Poorter et al., 2008, 2010; Keeling et al., 2008). Chave et al. (2009) further argued that mortality rates in tropical forests are associated with low-density wood, but this was not confirmed by our results, in which we did not find any significant difference in mortality rates between ES and LS plots (Table 3). However, M. kilimandscharica, the
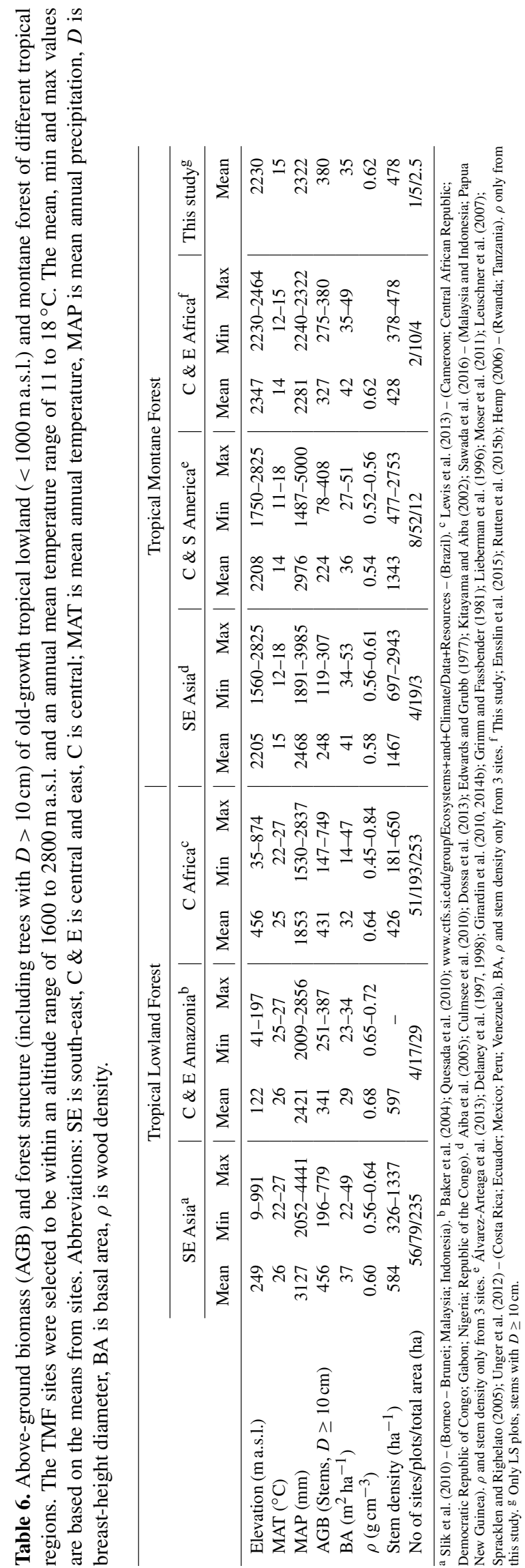

Biogeosciences, 14, 1285-1303, 2017 
most abundant ES species, had a significantly higher mortality rate than $S$. guineense, the most abundant LS species.

Overall the observations in this study support hypothesis \#3: "it is critical to account for variation in allometric relations and $\rho$ when quantifying and comparing forest biomass at different successional stages, since ES and LS species differ in these traits". It is therefore likely that a full recovery of the $\mathrm{C}$ stock not will be achieved before the first generation of ES trees have been replaced by LS trees.

\subsection{Biomass and C stocks in relation to studies of old-growth TMF}

To put our results into perspective, we compiled data from studies of AGB (trees with $D>10 \mathrm{~cm}$ ) of old-growth tropical lowland forest $(<1000 \mathrm{~m}$ a.s.l.) and TMF (elevations of 1600 to $2800 \mathrm{~m}$ a.s.l. and mean annual temperature of 11 to $18^{\circ} \mathrm{C}$, ca. $\pm 300 \mathrm{~m}$ and $\pm 2.5^{\circ} \mathrm{C}$ of our lowest and highest elevation and temperature; Table 6). The late successional (LS) stands of the Nyungwe TMF were shown to have somewhat higher AGB than the average old-growth lowland tropical forests of central/eastern Amazonia $(+11 \%)$ and a bit lower than lowland forests of central Africa $(-11 \%)$ and Borneo $(-15 \%$; Table 6). Average stem density, basal area and $\rho$ in our LS stands were similar to those observed in lowland tropical forests. These findings support the suggestion by Spracklen and Righelato (2014) that TMF biomass may store more C than expected.

Compared to the average AGB of the TMFs in south-east Asia and Central and South America, our LS plots had substantially higher AGB (Table 6). Only two plots from the studies in Central and South America (Delaney et al., 1997; Álvarez-Arteaga et al., 2013) had similar AGB to our average LS AGB (395 and $408 \mathrm{Mg} \mathrm{ha}^{-1}$ ). However, the AGB in these studies may be overestimated as none of them used $H$ as a parameter in the AGB calculation, an omission which may overestimate the biomass in TMFs (Girardin et al., 2010). When we applied the allometric equations from Delaney et al. (1997) to our data we obtained a $20 \%$ higher AGB than when using the equation from Chave et al. (2014), including $H$ as a parameter (see further discussion in Sect. 4.3). The only study of undisturbed TMF at the selected altitudes and temperatures from the African continent that we found (Ensslin et al., 2015; Rutten et al., 2015b) reported lower AGB $\left(275 \mathrm{Mgha}^{-1}\right)$ than in our LS plots but higher than average AGB in the American and Asian TMF studies (Table 6). Although AGB data from African TMFs are still scarce, the general pattern of higher AGB in Africa compared to America observed in tropical lowland rainforests (Banin et al., 2012; Feldpausch et al., 2012; Lewis et al., 2013) may thus hold also for TMFs, as also suggested by Ensslin et al. (2015).

TMF soils are considered to be richer in soil $\mathrm{C}$ content than lowland tropical forest (Roman et al., 2011), which has on average $46 \%$ of the total ecosystem $\mathrm{C}$ stock in the soil down to $1 \mathrm{~m}$ (Malhi et al., 2015). Taking into account that an average tropical forest soil has around $25 \%$ of the $\mathrm{C}$ content between our sampling depth (average $0.56 \mathrm{~m}$ ) and $1 \mathrm{~m}$ (Jobbágy and Jackson, 2000), the soil C fraction in the LS plots was $51 \%$, which was similar to an study in an old-growth TMF in Venezuela observing $52 \%$ (Delaney et al., 1997), but much higher than in a natural submotane rainforest in Sulawesi having only $32 \%$ of the $\mathrm{C}$ in the soil (Kessler et al., 2012). Only a few TMF studies have reported the $C$ stock of both below and above-ground compartments, which makes it difficult to assess the portioning of $\mathrm{C}$ in these ecosystems. In addition, comparing the below-ground $\mathrm{C}$ stock of different studies is probably less reliable than comparing aboveground $\mathrm{C}$ stocks. This is because of inconsistent sample methodology (e.g. regarding sampling depth and intensity; Roman et al., 2011) combined with the likelihood of large local variation in below-ground $\mathrm{C}$ stocks, especially in mountain areas where the vertical soil profile may be very variable due to variation, e.g. in sloping degree.

Based on available data, our total below-ground $\mathrm{C}$ stock is similar to the levels reported for studies in South American TMFs, when adjusted for differences in sampling depth (Delaney et al., 1997; Grimm and Fassbender, 1981; Girardin et al., 2010; Moser et al., 2011). However, the partitioning of below-ground $\mathrm{C}$ in the present study differs greatly from studies in the Andes by Girardin et al. (2010) and Moser et al. (2011) which were the only studies providing detailed below-ground compartmental $\mathrm{C}$ stock information. In our study, the $\mathrm{C}$ stock of the mineral soil down to $30 \mathrm{~cm}$ depth was more than three times as large as in the Andean TMFs, while the $\mathrm{C}$ stock of the soil organic layer plus fine roots was only half. The main reasons for this difference in soil C partitioning were that the mineral soil in the present study had very high $\mathrm{C}$ concentrations $(4-7 \%$ in top $30 \mathrm{~cm}$ ) while the organic soil layer was more shallow $(11 \mathrm{~cm})$ compared to the Andean studies $(31 \mathrm{~cm})$.

Overall, the observation of high above- and below-ground C stocks in our LS plots, as well as in Ensslin et al. (2015) support hypothesis \#4: "C stocks are higher in the African TMF studied here compared to TMFs in South America". However, ecosystem C stock data from African TMF studies are still scarce and there is a risk for biased results among TMF studies as the average plot size in TMF studies is small ( 0.22 ha in our compilation in Table 6$)$.

\section{Conclusion}

The results of this study demonstrate that tropical montane forests in central Africa contain large amounts of C. Undisturbed forests (i.e. LS stands) have higher AGB than their South American montane counterparts, a finding consistent with comparisons of lowland neo- and palaeotropical forests (Malhi et al., 2013b). The study also showed that AGB was greater in LS than ES stands, with both species composi- 
tion and stem properties (density and allometry) explaining this difference. Both $\rho$ and the $H$ to $D$ ratio of large trees were greater in LS than in ES tree species, highlighting the importance of accounting for these differences when quantifying the $\mathrm{C}$ stock of TMFs at different successional stages. Although LS and ES forests differed in AGB, they had similar NPP. This was the net result of counterbalancing effects of differences in biomass (higher in LS) and relative growth rates (higher in ES). While more work is needed to understand and estimate the $\mathrm{C}$ stocks and dynamics of African tropical montane forests, this study provides an important contribution towards that goal and highlights the importance of accounting for disturbance regimes and successional stages of forest.

Data availability. The above-ground biomass data referred to in this study are archived at and available from the Dryad Digital Repository; http://dx.doi.org/10.5061/dryad.b5b4h (Nyirambangutse et al., 2017).

\section{The Supplement related to this article is available online at doi:10.5194/bg-14-1285-2017-supplement.}

Author contributions. Brigitte Nyirambangutse and Göran Wallin planned and designed the experiment with important contributions from Donat Nsabimana, Elias Bizuru and Håkan Pleijel. Etienne Zibera, Brigitte Nyirambangutse, Félicien K. Uwizeye and Göran Wallin conducted the field measurements and data compilations. All authors contributed to the analysis and interpretation of the results. Brigitte Nyirambangutse and Göran Wallin wrote the manuscript with Håkan Pleijel and Johan Uddling, providing important editorial advice. All authors read and approved the final manuscript.

Competing interests. The authors declare that they have no conflict of interest.

Acknowledgements. Many thanks are due to Innocent $\mathrm{Ru}-$ sizana, Pierre Niyontegereje, Jean Baptiste Gakima, Ferdinand Ngayabahiga and Isaacar Ndayisabye for great assistance of the field work and to Mats Räntfors for lab assistance. The study was made possible by financial support from University of Rwanda - Sweden program for Research, Higher Education and Institutional Advancement, financed by Swedish International Development Cooperation Agency (Sida) and the Strategic Research Area "Biodiversity and Ecosystem Services in a Changing Climate" (BECC). We are also grateful to Rwanda Development Board (RDB) for the authorization to conduct research and collect specimens in Nyungwe National Park.

Edited by: J. Schöngart

Reviewed by: G. Moser and one anonymous referee

\section{References}

Aiba, S., Takyu, M., and Kitayama, K.: Dynamics, productivity and species richness of tropical rainforests along elevational and edaphic gradients on Mount Kinabalu, Borneo, Ecol. Res., 20, 279-286, doi:10.1007/s11284-005-0043-z, 2005.

Alamgira, M., Turtona, S. M., Macgregora, C. J., and Perta, P. L.: Assessing regulating and provisioning ecosystem services in a contrasting tropical forest landscape, Ecol. Indic., 64, 319-334, doi:10.1016/j.ecolind.2016.01.016, 2016.

Álvarez-Arteaga, G., García Calderón, N. E., Krasilnikov, P., and García-Oliva, F.: Carbon storage in montane cloud forests in Sierra Norte of Oaxaca, Mexico, Agrociencia, 47, 171-180, 2013.

Aragão, L. E. O. C., Malhi, Y., Metcalfe, D. B., Silva-Espejo, J. E., Jiménez, E., Navarrete, D., Almeida, S., Costa, A. C. L., Salinas, N., Phillips, O. L., Anderson, L. O., Alvarez, E., Baker, T. R., Goncalvez, P. H., Huamán-Ovalle, J., Mamani-Solórzano, M., Meir, P., Monteagudo, A., Patiño, S., Peñuela, M. C., Prieto, A., Quesada, C. A., Rozas-Dávila, A., Rudas, A., Silva Jr., J. A., and Vásquez, R.: Above- and below-ground net primary productivity across ten Amazonian forests on contrasting soils, Biogeosciences, 6, 2759-2778, doi:10.5194/bg-6-2759-2009, 2009.

Baker, T. R., Phillips, O. L., Malhi, Y., Almeida, S., Arroyo, L., Di Fiore, A., Erwin, T., Killeen, T. J., Laurance, S. G., Laurance, W. F., Lewis S. L., Llyod, J., Monteagudo, A., Neill, D. A., Patiño, S., Pitman, N. C. A., Silva, J. N. M., and Martinez, R. V.: Variation in wood density determines spatial patterns in Amazonian forest biomass, Glob. Change Biol., 10, 545-562, doi:10.1111/j.1365-2486.2004.00751.x, 2004.

Banin, L., Feldpausch, T. R., Phillips, O. L., Baker, T. R., Lloyd, J., Affum-Baffoe, K., Arets, E. J. M. M., Berry, N. J., Bradford, M., Brienen, R. J. W., and Davies, S.: What controls tropical forest architecture? Testing environmental, structural and floristic drivers, Global Ecol. Biogeogr., 21, 1179-1190, doi:10.1111/j.1466-8238.2012.00778.x, 2012.

Bastin, J. F., Barbier, N., Réjou-Méchain, M., Fayolle, A., GourletFleury, S., Maniatis, D., de Haulleville, T., Baya, F., Beeckman, H., Beina, D., and Couteron, P.: Seeing Central African forests through their largest trees, Sci. Rep., 5, doi:10.1038/srep13156, 2015.

Berenguer, E., Ferreira, J., Gardner, T. A., Aragão, L. E. O. C., De Camargo, P. B., Cerri, C. E., Durigan, M., Oliveira, R. C. D., Vieira, I. C. G., and Barlow, J.: A large-scale field assessment of carbon stocks in human-modified tropical forests, Glob. Change Biol., 20, 3713-3726, doi:10.1111/gcb.12627, 2014.

Birdsey, R. and Pan, Y.: Trends in management of the world's forests and impacts on carbon stocks, Forest Ecol. Manag., 355, 83-90, doi:10.1016/j.foreco.2015.04.031, 2015.

Bloesch, U., Troupin, G., and Derungs, N.: Les plantes ligneuses du Rwanda: flore, écologie et usage, Shaker Verlag, Aachen, Germany, 2009.

Brown, S. and Lugo, A. E.: Tropical secondary forests, J. Trop. Ecol., 6, 1-32, doi:10.1017/S0266467400003989, 1990.

Bruijnzeel, L. A. and Veneklaas, E. J.: Climatic conditions and tropical montane forest productivity: the fog has not lifted yet, Ecology, 79, 3-9, 1998.

Cairns, M. A., Brown, S., Helmer, E. H., and Baumgardner, G. A.: Root biomass allocation in the world's upland forests, Oecologia, 111, 1-11, 1997. 
Chave, J., Andalo, C., Brown, S., Cairns, M. A., Chambers, J. Q., Eamus, D., Fölster, H., Fromard, F., Higuchi, N., Kira, T., and Lescure, J. P.: Tree allometry and improved estimation of carbon stocks and balance in tropical forests, Oecologia, 145, 87-99, doi:10.1007/s00442-005-0100-x, 2005.

Chave, J., Coomes, D., Jansen, S., Lewis, S. L., Swenson, N. G., and Zanne, A. E.: Towards a worldwide wood economics spectrum, Ecol. Lett., 12, 351-366, doi:10.1111/j.14610248.2009.01285.x, 2009.

Chave, J., Réjou-Méchain, M., Búrquez, A., Chidumayo, E., Colgan, M. S., Delitti, W. B., Duque, A., Eid, T., Fearnside, P. M., Goodman, R. C., and Henry, M.: Improved allometric models to estimate the aboveground biomass of tropical trees, Glob. Change Biol., 20, 3177-3190, doi:10.1111/gcb.12629, 2014.

Chokkalingam, U. and de Jong, W.: Secondary forest: a working definition and typology, Int. Forest Rev., 3, 19-26, 2001.

Cizungu, L., Staelens, J., Huygens, D., Walangululu, J., Muhindo, D., Van Cleemput, O., and Boeckx, P.: Litterfall and leaf litter decomposition in a central African tropical mountain forest and Eucalyptus plantation, Forest Ecol. Manag., 326, 109-116, doi:10.1016/j.foreco.2014.04.015, 2014.

Clark, D. A., Brown, S., Kicklighter, D. W., Chambers, J. Q., Thomlinson, J. R., Ni, J., and Holland, E. A.: Net primary production in tropical forests: an evaluation and synthesis of existing field data, Ecol. Appl., 11, 371-384, 2001.

Culmsee, H., Leuschner, C., Moser, G., and Pitopang, R.: Forest aboveground biomass along an elevational transect in $\mathrm{Su}-$ lawesi, Indonesia, and the role of Fagaceae in tropical montane rain forests, J. Biogeogr., 37, 960-974, doi:10.1111/j.13652699.2009.02269.x, 2010.

Costanza, R., d'Arge R., de Groot, R., Farber,S., Grasso, M., Hannon, B., Limburg, K., Naeem, S., O’Neill, R. V., Paruelo, J., Raskin, R.G., Suttonk, P., and van den Belt, M.: The value of the world's ecosystem services and natural capital, Nature, 387, 253-260, 1997.

Delaney, M., Brown, S., Lugo, A. E., Torres-Lezama, A., and Bello Quintero, N.: The distribution of organic carbon in major components of forests located in five life zones of Venezuela, J. Trop. Ecol., 13, 697-708, doi:10.1017/S0266467400010877, 1997.

Delaney, M., Brown, S., Lugo, A. E., Torres-Lezama, A., and Bello Quintero, N.: The quantity and turnover of dead wood in permanent forest plots in six life zones of Venezuela, Biotropica, 30, 2-11, 1998.

Dossa, G. G. O., Paudel, E., Fujinuma, J., Yu, H., Chutipong, W., Zhang, Y., Paz, S., and Harrison, R. D.: Factors determining forest diversity and biomass on a tropical volcano, Mt. Rinjani, Lombok, Indonesia, PLoS ONE, 8, e67720, doi:10.1371/journal.pone.0067720, 2013.

Doughty, C. E., Metcalfe, D. B., da Costa, M. C., de Oliveira, A. A., Neto, G. F. C., Silva, J. A., Aragão, L. E., Almeida, S. S., Quesada, C. A., Girardin, C. A. J., and Halladay, K.: The production, allocation and cycling of carbon in a forest on fertile terra preta soil in eastern Amazonia compared with a forest on adjacent infertile soil, Plant Ecol. Divers., 7, 41-53, doi:10.1080/17550874.2013.798367, 2014.

Edwards, P. J. and Grubb, P. J.: Studies of mineral cycling in a montane rain forest in New Guinea, I. The distribution of organic matter in the vegetation and soil, J. Ecol., 65, 943-969, 1977.
Ensslin, A., Rutten, G., Pommer, U., Zimmermann, R., Hemp, A., and Fischer, M.: Effects of elevation and land use on the biomass of trees, shrubs and herbs at Mount Kilimanjaro, Ecosphere, 6, 1-15, doi:10.1890/ES14-00492.1, 2015.

FAO: Global forest resources assessment 2010, Food and Agriculture Organization of the United Nations, Rome, Italy, 2010.

Fashing, P. J., Mulindahabi, F., Gakima, J. B., Masozera, M., Mununura, I., Plumptre, A. J., and Nguyen, N.: Activity and ranging patterns of Colobus angolensis ruwenzorii in Nyungwe Forest, Rwanda: possible costs of large group size, Int. J. Primatol., 28, 529-550, doi:10.1007/s10764-006-9095-3, 2007.

Fehse, J., Hofstede, R., Aguirre, N., Paladines, C., Kooijman, A., and Sevink, J.: High altitude tropical secondary forests: a competitive carbon sink?, Forest Ecol. Manag., 163, 9-25, 2002.

Feintrenie L.: Agro-industrial plantations in Central Africa, risks and opportunities, Biodivers Conserv., 23, 1577-1589, doi:10.1007/s10531-014-0687-5, 2014.

Feldpausch, T. R., Banin, L., Phillips, O. L., Baker, T. R., Lewis, S. L., Quesada, C. A., Affum-Baffoe, K., Arets, E. J. M. M., Berry, N. J., Bird, M., Brondizio, E. S., de Camargo, P., Chave, J., Djagbletey, G., Domingues, T. F., Drescher, M., Fearnside, P. M., França, M. B., Fyllas, N. M., Lopez-Gonzalez, G., Hladik, A., Higuchi, N., Hunter, M. O., Iida, Y., Salim, K. A., Kassim, A. R., Keller, M., Kemp, J., King, D. A., Lovett, J. C., Marimon, B. S., Marimon-Junior, B. H., Lenza, E., Marshall, A. R., Metcalfe, D. J., Mitchard, E. T. A., Moran, E. F., Nelson, B. W., Nilus, R., Nogueira, E. M., Palace, M., Patiño, S., Peh, K. S.H., Raventos, M. T., Reitsma, J. M., Saiz, G., Schrodt, F., Sonké, B., Taedoumg, H. E., Tan, S., White, L., Wöll, H., and Lloyd, J.: Height-diameter allometry of tropical forest trees, Biogeosciences, 8, 1081-1106, doi:10.5194/bg-8-1081-2011, 2011.

Feldpausch, T. R., Lloyd, J., Lewis, S. L., Brienen, R. J. W., Gloor, M., Monteagudo Mendoza, A., Lopez-Gonzalez, G., Banin, L., Abu Salim, K., Affum-Baffoe, K., Alexiades, M., Almeida, S., Amaral, I., Andrade, A., Aragão, L. E. O. C., Araujo Murakami, A., Arets, E. J. M. M., Arroyo, L., Aymard C., G. A., Baker, T. R., Bánki, O. S., Berry, N. J., Cardozo, N., Chave, J., Comiskey, J. A., Alvarez, E., de Oliveira, A., Di Fiore, A., Djagbletey, G., Domingues, T. F., Erwin, T. L., Fearnside, P. M., França, M. B., Freitas, M. A., Higuchi, N., E. Honorio C., Iida, Y., Jiménez, E., Kassim, A. R., Killeen, T. J., Laurance, W. F., Lovett, J. C., Malhi, Y., Marimon, B. S., Marimon-Junior, B. H., Lenza, E., Marshall, A. R., Mendoza, C., Metcalfe, D. J., Mitchard, E. T. A., Neill, D. A., Nelson, B. W., Nilus, R., Nogueira, E. M., Parada, A., Peh, K. S.-H., Pena Cruz, A., Peñuela, M. C., Pitman, N. C. A., Prieto, A., Quesada, C. A., Ramírez, F., Ramírez-Angulo, H., Reitsma, J. M., Rudas, A., Saiz, G., Salomão, R. P., Schwarz, M., Silva, N., Silva-Espejo, J. E., Silveira, M., Sonké, B., Stropp, J., Taedoumg, H. E., Tan, S., ter Steege, H., Terborgh, J., TorelloRaventos, M., van der Heijden, G. M. F., Vásquez, R., Vilanova, E., Vos, V. A., White, L., Willcock, S., Woell, H., and Phillips, O. L.: Tree height integrated into pantropical forest biomass estimates, Biogeosciences, 9, 3381-3403, doi:10.5194/bg-9-33812012, 2012.

Fischer, E. and Killmann, D.: Illustrated field guide to the plants of Nyungwe National Park Rwanda, Koblenz Geographical Colloquia, Series Biogeographical Monographs, Oberreifenberg, Germany, 2008. 
Gharahi Ghehi, N. G., Werner, C., Hufkens, K., Kiese, R., Van Ranst, E., Nsabimana, D., Wallin, G., Klemedtsson, L., Butterbach-Bahl, K., and Boeckx, P.: $\mathrm{N}_{2} \mathrm{O}$ and $\mathrm{NO}$ emission from the Nyungwe tropical highland rainforest in Rwanda, Geoderma Regional, 2, 41-49, doi:10.1016/j.geodrs.2014.09.008, 2014

Gibbs, H. K., Brown, S., Niles, J. O., and Foley, J. A.: Monitoring and estimating tropical forest carbon stocks: making REDD a reality, Environ. Res. Lett., 2, 045023, doi:10.1088/17489326/2/4/045023, 2007.

Girardin, C. A. J., Malhi, Y., Aragão, L. E. O. C., Mamani, M., Huaraca Huasco, W., Durand, L., Feeley, K. J., Rapp, J., SilvaEspejo, J. E., Silman, M., and Salinas, N.: Net primary productivity allocation and cycling of carbon along a tropical forest elevational transect in the Peruvian Andes, Glob. Change Biol., 16, 3176-3192, doi:10.1111/j.1365-2486.2010.02235.x, 2010.

Girardin, C. A. J., Espejob, J. E. S. , Doughty, C. E., Huasco, W. H., Metcalfe, D. B., Durand-Baca, L., Marthews, T. R., Aragão, L. E., Farfán-Rios, W., García-Cabrera, K., and Halladay, K.: Productivity and carbon allocation in a tropical montane cloud forest in the Peruvian Andes, Plant Ecol. Divers., 7, 107-123, doi:10.1080/17550874.2013.820222, 2014a.

Girardin, C. A. J., Farfan-Rios, W., Garcia, K., Feeley, K. J., Jørgensen, P. M., Murakami, A. A., Cayola Pérez, L., Seidel, R., Paniagua, N., Fuentes Claros, A. F., and Maldonado, C.: Spatial patterns of above-ground structure, biomass and composition in a network of six Andean elevation transects, Plant Ecol. Divers., 7, 161-171, doi:10.1080/17550874.2013.820806, 2014b.

Grimm, U. and Fassbender, H. W.: Ciclos bioquímicos en un ecosistema forestal de los Andes Occidentales de Venezuela, I. Inventario de las reservas organicas y minerales $(\mathrm{N}, \mathrm{P}, \mathrm{K}, \mathrm{Ca}, \mathrm{Mg}$, Mn, Fe, Al, Na), Turrialba, 31, 27-37, 1981.

Gross-Camp, N. D., Martin, A., McGuire, S., Kebede, B., and Munyarukaza, J.: Payments for ecosystem services in an African protected area: exploring issues of legitimacy, fairness, equity and effectiveness, Oryx, 46, 24-33, doi:10.1017/S0030605311001372, 2012.

Gustafsson, M., Gustafsson, L., Alloysius, D., Falck, J., Yap, S., Karlsson, A., and Ilstedt, U.: Life history traits predict the response to increased light among 33 tropical rainforest tree species, Forest Ecol. Manag., 362, 20-28, doi:10.1016/j.foreco.2015.11.017, 2016.

Hemp, A.: Continuum or zonation? Altitudinal gradients in the forest vegetation of Mt. Kilimanjaro, Plant Ecol., 184, 27-42, doi:10.1007/s11258-005-9049-4, 2006.

Hertel, D., Moser, G., Culmsee, H., Erasmi, S., Horna, V., Schuldt, B., and Leuschner, Ch.: Below- and above-ground biomass and net primary production in a paleotropical natural forest $(\mathrm{Su}-$ lawesi, Indonesia) as compared to neotropical forests, Forest Ecol. Manag., 258, 1904-1912, 2009.

Huasco, W. H., Girardin, C. A. J., Doughty, C. E., Metcalfe, D. B., Baca, L. D., Silva-Espejo, J. E., Cabrera, D. G., Aragão, L. E., Davila, A. R., Marthews, T. R., and HuaracaQuispe, L. P.: Seasonal production, allocation and cycling of carbon in two mid-elevation tropical montane forest plots in the Peruvian Andes, Plant Ecol. Divers., 7, 125-142, doi:10.1080/17550874.2013.819042, 2014.

Jara, M. C., Henry, M., Réjou-Méchain, M., Wayson, C., ZapataCuartas, M., Piotto, D., Guier, F. A., Lombis, H. C., López, E. C.,
Lara, R. C., and Rojas, K. C.: Guidelines for documenting and reporting tree allometric equations, Ann. Forest Sci., 72, 763768, doi:10.1007/s13595-014-0415-z, 2015.

Jobbágy, E. G. and Jackson, R. B.: The vertical distribution of soil organic carbon and its relation to climate and vegetation, Ecol. Appl., 10, 423-436, 2000.

Kearsley, E., de Haulleville, T., Hufkens, K., Kidimbu, A., Toirambe, B., Baert, G., Huygens, D., Kebede, Y., Defourny, P., Bogaert, J., and Beeckman, H.: Conventional tree heightdiameter relationships significantly overestimate aboveground carbon stocks in the Central Congo Basin, Nat. Commun., 4, 2269, doi:10.1038/ncomms3269, 2013.

Keeling, H. C., Baker, T. R., Martinez, R. V., Monteagudo, A., and Phillips, O. L.: Contrasting patterns of diameter and biomass increment across tree functional groups in Amazonian forests, Oecologia, 158, 521-534, doi:10.1038/ncomms3269, 2008.

Kessler, M., Hertel, D., Jungkunst, H. F., Kluge, J., Abrahamczyk, S., Bos, M., Buchori, D., Gerold, G., Gradstein, S. R., Köhler, S., Leuschner, C., Moser, G., Pitopang, R., Saleh, S., Schulze, C. H., Sporn, S. G., Steffen-Dewenter, I., Tjitrosoedirdjo, S. S., and Tscharntke, T.: Can joint carbon and biodiversity management in tropical agroforestry landscapes be optimized?, PLoS ONE, 7, e47192, doi:10.1371/journal.pone.0047192, 2012.

Ketterings, Q. M., Coe, R., van Noordwijk, M., and Palm, C. A.: Reducing uncertainty in the use of allometric biomass equations for predicting above-ground tree biomass in mixed secondary forests, Forest Ecol. Manag., 146, 199-209, 2001.

Kindt, R., van Breugel, P., Lillesö J.-P. B., Minani, V., Ruffo, C. K., Gapsi J., Jamnadass, R., and Graudal L.: Potential natural vegetation of eastern Africa, Volume 9, Atlas and tree species composition for Rwanda, Department of Geoscience and Natural Resource Mangement, University of Copenhagen, Copenhagen, Denmark, 2014

King, D. A.: Allometry and life history of tropical trees, J. Trop. Ecol., 12, 25-44, doi:10.1017/S0266467400009299, 1996.

Kitayama, K. and Aiba S.: Ecosystem structure and productivity of tropical rain forests along altitudinal gradients with contrasting soil phosphorus pools on Mount Kinabalu, Borneo, J. Ecol., 90, 37-51, 2002.

Lawton, R. O.: Ecological Constraints on Wood Density in a Tropical Montane Rain Forest, Am. J. Bot., 71, 261-267,1984.

Leuschner, C., Moser, G., Bertsch, C., Roderstein, M., and Hertel, D.: Large altitudinal increase in tree root/shoot ratio in tropical mountain forests of Ecuador, Basic Appl. Ecol., 8, 219-230, doi:10.1016/j.baae.2006.02.004, 2007.

Lewis, S. L., Phillips, O. L., Sheil, D., Vinceti, B., Baker, T. R., Brown, S., Graham, A. W., Higuchi, N., Hilbert, D. W., Laurance, W. F., and Lejoly, J.: Tropical forest tree mortality, recruitment and turnover rates: calculation, interpretation and comparison when census intervals vary, J. Ecol., 92, 929-944, 2004.

Lewis, S. L., Lopez-Gonzalez, G., Sonké, B., Affum-Baffoe, K., Baker, T. R., Ojo, L. O., Phillips, O. L., Reitsma, J. M., White, L., Comiskey, J. A., Djuikouo K, M.-N., Ewango, C. E. N., Feldpausch, T. R., Hamilton, A. C., Gloor, M., Hart, T., Hladik, A., Lloyd, J., Lovett, J. C., Makana, J.-R., Malhi, Y., Mbago, F. M., Ndangalasi, H. J., Peacock, J., Peh, K. S.-H., Sheil, D., Sunderland, T., Swaine, M. D., Taplin, J., Taylor, D., Thomas, S. C., Votere, R., and Wöll, H.: Increasing carbon stor- 
age in intact African tropical forests, Nature, 457, 1003-1006, doi:10.1038/nature07771, 2009.

Lewis, S. L., Sonké, B., Sunderland, T., Begne, S. K., LopezGonzalez, G., Van Der Heijden, G. M., Phillips, O. L., AffumBaffoe, K., Baker, T. R., Banin, L., and Bastin, J. F.: Aboveground biomass and structure of 260 African tropical forests, Philos. T. R. Soc. B, 368, 20120295, doi:10.1098/rstb.2012.0295, 2013.

Lewis, S. L., Edwards, D. P., and Galbraith, D.: Increasing human dominance of tropical forests, Science, 349, 827-832, doi:10.1126/science.aaa9932, 2015.

Lieberman, D., Lieberman, M., Peralta, R., and Hartshorn, G. S.: Tropical forest structure and composition on a large-scale altitudinal gradient in Costa Rica, J. Ecol., 84, 137-152, 1996.

Liebsch, D., Marques M. C. M., and Goldenberg, R.: How long does the Atlantic Rain Forest take to recover after a disturbance? Changes in species composition and ecological features during secondary succession, Biol. Conserv., 141, 1717-1725, doi:10.1016/j.biocon.2008.04.013, 2008.

Malhi, Y., Doughty, C., and Galbraith, D.: The allocation of ecosystem net primary productivity in tropical forests, Philos. T. R. Soc. B., 366, 3225-3245, doi:10.1098/rstb.2011.0062, 2011.

Malhi, Y., Adu-Bredu, S., Asare, R. A., Lewis, S. L., and Mayaux, P.: The past, present and future of Africa's rainforests, Philos. T. R. Soc. B, 368, 20120293, doi:10.1098/rstb.2012.0293, 2013a.

Malhi, Y., Adu-Bredu, S., Asare, R. A., Lewis, S. L., and Mayaux, P.: African rainforests: past, present and future, Philos. T. R. Soc. B, 368, 20120312, doi:10.1098/rstb.2012.0312, 2013 b.

Malhi, Y., Farfán Amézquita, F., Doughty, C. E., Silva-Espejo, J. E., Girardin, C. A. J., Metcalfe, D. B., Aragão, L. E., Huaraca-Quispe, L. P., Alzamora-Taype, I., Eguiluz-Mora, L., and Marthews, T. R.: The productivity, metabolism and carbon cycle of two lowland tropical forest plots in southwestern Amazonia, Peru, Plant Ecol. Divers., 7, 85-105, doi:10.1080/17550874.2013.820805, 2014a.

Malhi, Y., Gardner, T. A., Goldsmith, G. R., Silman, M. R., and Zelazowski, P.: Tropical forests in the Anthropocene, Annu. Rev. Environ. Resour., 39, 125-159, doi:10.1146/annurev-environ030713-155141, 2014b.

Malhi, Y., Moore, S., and Riutta, T.: Forest carbon budgets and climate change, in: Routledge Handbook of Forest ecology, edited by: Peh, K., Cortlett, R., and Bergeron, Y., Routledge, Oxford, UK, 517-526, 2015.

Martin, A. R. and Thomas, S. C.: A reassessment of carbon content in tropical trees, PLoS ONE, 6, 23533, doi:10.1371/journal.pone.0023533, 2011.

Martin, P. A., Newton, A., and Bullock, J. M.: Carbon pools recover more quickly than plant biodiversity in tropical secondary forests, Philos. T. R. Soc. B, 280, 20132236, doi:10.1098/rspb.2013.2236, 2013.

Martínez, M. L., Pérez-Maqueo, O., Vázquez, G., CastilloCampos, G., García-Franco, J., Mehltreter, K., Equihua, M., and Landgrave, R.: Effects of land use change on biodiversity and ecosystem services in tropical montane cloud forests of Mexico, Forest Ecol. Manag., 258, 1856-1863, doi:10.1016/j.foreco.2009.02.023, 2009.

Masozera, M. K. and Alavalapati, J. R.: Forest dependency and its implications for protected areas management: a case study from the Nyungwe Forest Reserve, Rwanda, Scand. J. For. Res., 19, 85-92, doi:10.1080/14004080410034164, 2004.

Masozera, M. K., Alavalapati, J. R., Jacobson, S. K., and Shrestha, R. K.: Assessing the suitability of community-based management for the Nyungwe Forest Reserve, Rwanda, For. Policy Econ., 8, 206-216, doi:10.1016/j.forpol.2004.08.001, 2006.

Metcalf, C. J. E., Clark, J. S., and Clark, D. A.: Tree growth inference and prediction when the point of measurement changes: modelling around buttresses in tropical forests, J. Trop. Ecol., 25, 1-12, doi:10.1017/S0266467408005646, 2009.

Metcalfe, D. B., Williams, M., Aragão, L. E. O. C., Da Costa, A. C. L., De Almeida, S. S., Braga, A. P., Gonçalves, P. H. L., De Athaydes, J., Junior, S., Malhi, Y., and Meir, P.: A method for extracting plant roots from soil which facilitates rapid sample processing without compromising measurement accuracy, New Phytol., 174, 697-703, doi:10.1111/j.1469-8137.2007.02032.x, 2007.

Moser, G., Leuschner, C., Hertel, D., Graefe, S., Soethe, N., and Iost, S.: Elevation effects on the carbon budget of tropical mountain forests (S Ecuador): the role of the belowground compartment, Glob. Change Biol., 17, 2211-2226, doi:10.1111/j.13652486.2010.02367.x, 2011.

Muller-Landau, H. C.: Interspecific and inter-site variation in wood specific gravity of tropical trees, Biotropica, 36, 20-32, 2004.

Ndayisabye, I.: Biomass and diversity of understory vegetation in Nyungwe montane rain forest, Bachelor thesis, University of Rwanda, Rwanda, 2014.

Ngomanda, A., Mavouroulou, Q. M., Obiang, N. L. E., Iponga, D. M., Mavoungou, J. F., Lépengué, N., Picard, N., and Mbatchi, B.: Derivation of diameter measurements for buttressed trees, an example from Gabon, J. Trop. Ecol., 28, 299-302, doi:10.1017/S0266467412000144, 2012.

Noormets, A., Epron, D., Domec, J. C., McNulty, S. G., Fox, T., Sun, G., and King, J. S.: Effects of forest management on productivity and carbon sequestration: A review and hypothesis, Forest Ecol. Manag., 355, 124-140, doi:10.1016/j.foreco.2015.05.019, 2015.

Nsabimana, D.: Carbon stock and fluxes in Nyungwe forest and Ruhande Arboretum in Rwanda, PhD thesis, University of Gothenburg, Gothenburg, Sweden, 2009.

Pan, Y., Birdsey, R. A., Fang, J., Houghton, R., Kauppi, P. E., Kurz, W. A., Phillips, O. L., Shvidenko, A., Lewis, S. L., Canadell, J. G., and Ciais, P.: A large and persistent carbon sink in the world's forests, Science, 333, 988-993, doi:10.1126/science.1201609, 2011.

Peña-Claros, M.: Changes in Forest Structure and Species Composition during Secondary Forest Succession in the Bolivian Amazon, Biotropica, 35, 450-461, 2003.

Phillips, O. L., Malhi, Y., Higuchi, N., Laurance, W. F., Núñez, P. V., Vásquez, R. M., Laurance, S. G., Ferreira, L. V., Stern, M., Brown, S., and Grace J.: Changes in the Carbon Balance of Tropical Forests: Evidence from Long-Term Plots, Science, 282, 439442, doi:10.1126/science.282.5388.439, 1998.

Plumptre, A. J., Masozera, M., Fashing, P. J., McNeilage, A., Ewango, C., Kaplin, B. A., and Liengola, I.: Biodiversity Surveys of the Nyungwe Forest of Southwest Rwanda, Working paper 19, Wildlife Conservation Society, Bronx, NY, USA, 2002.

Plumptre, A. J., Davenport, T. R., Behangana, M., Kityo, R., Eilu, G., Ssegawa, P., Ewango, C., Meirte, D., Kahindo, 
C., Herremans, M., and Peterhans, J. K.: The biodiversity of the Albertine Rift, Biol. Cons., 134, 178-194, doi:10.1016/j.biocon.2006.08.021, 2007.

Poorter, L., Wright, S. J., Paz, H., Ackerly, D. D., Condit, R., IbarraManríquez, G., Harms, K. E., Licona, J. C., Martínez-Ramos, M., Mazer, S. J., and Muller-Landau, H. C.: Are functional traits good predictors of demographic rates? Evidence from five neotropical forests, Ecology, 89, 1908-1920, 2008.

Poorter, L., McDonald, I., Alarcón, A., Fichtler, E., Licona, J. C., Peña-Claros, M., Sterck, F., Villegas, Z., and Sass-Klaassen, U.: The importance of wood traits and hydraulic conductance for the performance and life history strategies of 42 rainforest tree species, New Phytol., 185, 481-492, doi:10.1111/j.14698137.2009.03092.x, 2010.

Quesada, C. A., Lloyd, J., Schwarz, M., Patiño, S., Baker, T. R., Czimczik, C., Fyllas, N. M., Martinelli, L., Nardoto, G. B., Schmerler, J., Santos, A. J. B., Hodnett, M. G., Herrera, R., Luizão, F. J., Arneth, A., Lloyd, G., Dezzeo, N., Hilke, I., Kuhlmann, I., Raessler, M., Brand, W. A., Geilmann, H., Moraes Filho, J. O., Carvalho, F. P., Araujo Filho, R. N., Chaves, J. E., Cruz Junior, O. F., Pimentel, T. P., and Paiva, R.: Variations in chemical and physical properties of Amazon forest soils in relation to their genesis, Biogeosciences, 7, 1515-1541, doi:10.5194/bg-7-15152010, 2010.

Roman, L., Scatena, F. N.m and Bruijnzeel, L. A.: Global and local variatiobns in tropical montane cloud forest soils, in: Tropical montane cloud forests: Science for conservation and management, edited by: Bruijnzeel, L. A., Scatena F. N., and Hamilton, L. S., Cambridge University Press, New York, NY, USA, 77-89, 2011

Reich, P. B.: The world-wide "fast-slow" plant economics spectrum: a traits manifesto, J. Ecol., 102, 275-301, doi:10.1111/1365-2745.12211, 2014.

Rutten, G., Ensslin, A., Hemp, A., and Fischer, M.: Vertical and Horizontal Vegetation Structure across Natural and Modified Habitat Types at Mount Kilimanjaro, PLoS ONE, 10, e0138822, doi:10.1371/journal.pone.0138822, 2015a.

Rutten, G., Ensslin, A., Hemp, A., and Fischer, M.: Forest structure and composition of previously selectively logged and non-logged montane forests at Mt. Kilimanjaro, Forest Ecol. Manag., 337, 61-66, doi:10.1016/j.foreco.2014.10.036, 2015b.

Saugier, B., Roy, J., and Mooney, H. A.: Estimations of global terrestrial productivity: Converging toward a single number?, in: Terrestrial global productivity: past, present, and future, edited by: Roy, J., Saugier, B., and Mooney, H. A., Academic Press, San Diego, CA, USA, 543-557, 2001.

Sawada, Y., Aiba, S., Seino, T., and Kitayama, K.: Size structure, growth and regeneration of tropical conifers along a soil gradient related to altitude and geological substrates on Mount Kinabalu, Borneo, Plant Soil, 403, 103-114, doi:10.1007/s11104015-2722-z, 2016.

Scatena, F. N., Bruijnzeel, L. A., Bubb, P., and Das, S.: Setting the stage, in: Tropical montane cloud forests: Science for conservation and management, edited by: Bruijnzeel, L. A., Scatena, F. N., and Hamilton, L. S., Cambridge University Press, New York, NY, USA, 3-13, 2011

Sheil, D. and May, R. M.: Mortality and recruitment rate evaluations in heterogeneous tropical forests, J. Ecol., 84, 91-100, 1996.
Sierra, C. A., Del Valle, J. I., and Orrego, S. A.: Accounting for fine root mass sample losses in the washing process: a case study from a tropical montane forest of Colombia, J. Trop. Ecol., 19, 599-601, doi:10.1017/S0266467403003663, 2003.

Sierra, C. A., Del Valle, J. I., and Restrepo, H. I.: Total carbon accumulation in a tropical forest landscape, Carbon Balance Manag. 7, 12, doi:10.1186/1750-0680-7-12, 2012.

Slik, J. W. F., Aiba, S., Brearley, F. Q., Cannon, C. H., Forshed, O., Kitayama, K., Nagamasu, H., Nilus, R., Payne, J., Paoli, G., Poulsen, A. D., Raes, N., Sheil, D., Sidiyasa, K., Suzuki, E., and van Valkenburg, J. L. C. H.: Environmental correlates of tree biomass, basal area, wood specific gravity and stem density gradients in Borneo's tropical forests, Global Ecol. Biogeogr., 19, 50-60, doi:10.1111/j.1466-8238.2009.00489.x, 2010.

Slik, J. W. F., Paoli, G., McGuire, K., Amara, I., Barroso, J., Bastian, M., Blanc, L., Bongers, F., Boundja, P., Clark, C., Collins, M., Dauby, G., Ding, Y., Doucet, J.-L., Eler, E., Ferreira, L., Forshed, O., Fredriksson, G., Gillet, J.-F., Harris, D., Leal, M., Laumonier, Y., Malhi, Y., Mansor, A., Martin, E., Miyamoto, K., Nagamasu, A. A.-M., H., Nilus, R., Nurtjahya, E., Oliveira, A., Onrizal, O., Parada-Gutierrez, A., Permana, A., Poorter, L., Poulsen, J., Ramirez-Angulo, H., Reitsma, J., Rovero, F., Rozak, A., Sheil, D., Silva-Espejo, J., Silveira, M., Spironelo, W., ter Steege, H., Stevart, T., Navarro-Aguilar, G. E., Sunderland, T., Suzuki, E., Tang, J., Theilade, I., van der Heijden, G., van Valkenburg, J., Van Do, T., Vilanova, E., Vos, V., Wich, S., Wöll, H., Yoneda, T., Zang, R., Zhang, M.-G., and Zweifel, N.: Large trees drive forest aboveground biomass variation in moist lowland forests across the tropics, Global Ecol. Biogeogr., 22, 12611271, doi:10.1111/geb.12092, 2013.

Spracklen, D. V. and Righelato, R.: Carbon storage and sequestration in tropical montane forests of southern Ecuador, World Land Trust, Halesworth, Suffolk, UK, 2005.

Spracklen, D. V. and Righelato, R.: Tropical montane forests are a larger than expected global carbon store, Biogeosciences, 11, 2741-2754, doi:10.5194/bg-11-2741-2014, 2014.

Spracklen, D. V. and Righelato, R.: Carbon storage and sequestration of re-growing montane forests in southern Ecuador, Forest Ecol. Manag., 364, 139-144, doi:10.1016/j.foreco.2016.01.001, 2016.

Swaine, M. D. and Whitmore, T. C.: On the definition of ecological species groups in tropical rain forests, Vegetatio, 75, 81-86, 1988.

Tesfaye, G., Teketay, D., and Fetene, M.: Regeneration of fourteen tree species in Harenna forest, southeastern Ethiopia, Flora, 197, 461-474, 2002.

Unger, M., Homeier, J., and Leuschner, C.: Effects of soil chemistry on tropical forest biomass and productivity at different elevations in the equatorial Andes, Oecologia, 170, 263-274, doi:10.1007/s00442-012-2295-y, 2012.

Woodall, C. W., Russell, M. B., Walters, B. F., D’Amato, A. W., Zhu, K., and Saatchi, S. S.: Forest production dynamics along a wood density spectrum in eastern US forests, Trees, 29, 299-310, 2015.

Zanne, A. E., Lopez-Gonzalez, G., Coomes, D. A., Ilic, J., Jansen, S., Lewis, S.L., Miller, R. B., Swenson, N. G., Wiemann, M. C., and Chave, J.: Data from: Towards a worldwide wood economics spectrum, Dryad Digital Repository, doi:10.5061/dryad.234, 2009. 